Article

\title{
Improvement of Extracted Power of Pole Mounted Solar Panels by Effective Cooling Using Aluminum Heat Sink under Hot Weather and Variable Wind Speed Conditions
}

\author{
Youssef Hassan 1,2, Mohamed Orabi ${ }^{1}{ }^{\mathbb{D}}$, Abdulaziz Alshreef ${ }^{2}$, Omar M. Al-Rabghi ${ }^{3}$, \\ Badr A. Habeebullah ${ }^{3}$, Abdelali El Aroudi ${ }^{4 * *(D)}$ and Mohamed A. Ismeil 1,5 (D) \\ 1 Aswan Power Electronics Applications Research Center (APEARC), Faculty of Engineering, \\ Aswan University, Aswan 81542, Egypt; yousef.badry@aswu.edu.eg (Y.H.); orabi@ieee.org (M.O.); \\ melzanaty@apearc.aswu.edu.eg (M.A.I.) \\ 2 Department of Electrical and Computer Engeneering, King Abdulaziz University, P.O. Box 80204, \\ Jeddah 21589, Saudi Arabia; alshareef1379@yahoo.com \\ 3 Department of Mechanical Engeneering, King Abdulaziz University, P.O. Box 80204, \\ Jeddah 21589, Saudi Arabia; orabghi@kau.edu.sa (O.M.A.-R.); bhabeeb@kau.edu.sa (B.A.H.) \\ 4 Departament d'Enginyeria Electrònica, Universitat Rovira i Virgili, Elèctrica i Automàtica, \\ 43007 Tarragona, Spain \\ 5 Faculty of Engineering, South Valley University, Qena 83523, Egypt \\ * Correspondence: abdelali.elaroudi@urv.cat
}

Received: 12 May 2020; Accepted: 12 June 2020; Published: 18 June 2020

\begin{abstract}
The increase in operating temperature of PV generators leads to degradation of their performance. These adverse effects of high temperatures are considered as one of the most important problems that solar panel operation faces in hot weather areas. A lot of research has been undertaken to study this aspect and find ways of limiting the harm caused by such high temperatures. To overcome this harm and to maintain the operating temperature of the PV cells within the optimum range specified by manufacturers, cooling the solar panels often becomes indispensable. This paper discusses the heat transfer through the solar panel layers and studies the effect of high temperature on the solar panel performance in a hot desert environment. It also presents the development of a new solar panel structure viz. by installing an aluminum heat sink to reduce the effect of temperature rise and thus improve the solar panel performance. The study focuses on a pole-mounted solar panel for a street lighting apparatus in extremely hot desert conditions with fluctuating wind speeds. It will be shown that adding an aluminum heat sink to the solar panel bottom mitigates the effect of increased temperature and hence modifies the solar panel operating point by increasing both the efficiency and the lifetime. The solar cell temperature is decreased by $16.4 \%$ as a result of the aluminum heat sink installation on the solar panel back sheet and consequently, the accumulated energy produced by the the solar panel is increased by $13.23 \%$ per day.
\end{abstract}

Keywords: solar panel performance; photovoltaic (PV) cell; heat sink; back surface cooling of photovoltaic panel; solar panel and excessive heat

\section{Introduction}

Saudi Arabia is a leader in the field of fossil oil production in the Middle Eastern Gulf region. Nevertheless, in the recent years the country has made strides in harnessing new renewable energy sources to meet its energy requirements, mostly owing to the environmental sustainability of these energy sources [1]. Several investigations about solar radiation have been carried in Jeddah City 
(Saudi Arabia) which is considered a good example of a severe temperature case with the highest solar radiation values [2]. This research focuses on temperature mitigation of solar cells using a new improvement in solar panel structure. A literature review of the previous studies was performed. Many studies have indicated a reduction of the efficiency of solar panels under high temperature conditions [3-5]. Most traditional solutions are concerned with mitigation of the temperature effect via front surface cooling [6-12]. In [6] the active cooling is done by using power from $12 \mathrm{~V} 5.4 \mathrm{~W}$ batteries. The harvested energy has been compared to that obtained from the same source at a reference temperature of $20^{\circ} \mathrm{C}$, and a reduction of $45.5 \%$ was observed. In [7] active cooling has been used to study the effect of cooling on the PV characteristics, and it has been found that the module surface temperature has a direct effect on the open circuit voltage. The cooling increases the potential difference from $59 \mathrm{~V}$ to $62.3 \mathrm{~V}$. In [8], a 2.6\% increase in efficiency has been recorded with a $4.7 \%$ decrease in temperature. In addition, an increase of up to $8.4 \%$ has been recorded in the maximum power achieved. Uniform cooling has been presented in $[9,10]$ where the temperature has been found to decrease non-uniformly from an average of $3{ }^{\circ} \mathrm{C}$ to $1.8^{\circ} \mathrm{C}$ by employing jet cooling. Back surface cooling using water has been presented in [11-13]. This system achieved an increase in output power by about $12.5 \%$. A new direction for solar panel cooling depends on the design of thermal and optical characteristics of a solar cell by limiting the parasitic absorption by selective spectral cooling, and then by improving the radiative cooling [14]. All previous cooling systems are classified as active cooling systems which use electrical devices and mechanical systems requiring extra power. On the other hand, passive cooling is deployed to decrease the temperature with the help of additional parts such as heat sinks [15-20] without requiring additional power input. In [15] by using a designed heat sink, the temperature reduction in the range of $30^{\circ} \mathrm{C}-40^{\circ} \mathrm{C}$ has been achieved. In [16], using both active and passive methods, heat is released out the heat sink by forced air. Although this system helps in reducing the temperature, the use of more than one method leads to an increase in the cost and this set-up suffers from the disadvantage of the large size of the needed exchanger as compared to the size of the PV cell. In [17] an aluminum heat sink has been used to dissipate the temperature of photovoltaic (PV) cells. Though, it has a lower coefficient of thermal conduction, the advantage is that it is cheaper. Increases of $20 \%, 13 \%$, and $9 \%$ are achieved as regards efficiency, energy, and power conversion, respectively, by using the passive cooling technique. On the other hand, the energy can be increased by $14.4 \%$ at an ambient temperature of $15^{\circ} \mathrm{C}$. In [18] a simulation study has been done where the ribs of the heat sink have been demonstrated to decrease the temperate up to $10^{\circ} \mathrm{C}$ below the normal temperature. In [19] heat sink fins increase the solar panel performance by increasing the cooling. The highest reduction obtained in solar panel temperature has been a decrease from $60.6^{\circ} \mathrm{C}$ to $54.9^{\circ} \mathrm{C}$ on average by employing a heat sink as a passive cooling methodology. This represents a $9.4 \%$ reduction in the temperature, and it causes an increase in the average output power by of about $15.3 \%$. However, this study did not consider the variations of wind speed. Also, no design and selection for the heat sink has been performed. In [20] the cooling has been done by a heat sink as well as forced air and an average reduction of $10{ }^{\circ} \mathrm{C}$ in temperature has been achieved. The decrease in temperature achieved by the heat sink results in an increase in the open circuit voltage Voc and maximum power Pmpp by $10 \%$ and $18.67 \%$, respectively. In [21] a steady state analysis of solar radiation falling on the solar panel surface was performed to obtain the amount of useful energy as well as thermal energy losses. The present work studies the effect of attaching an aluminum heat sink to the solar panel back surface to enable the heat transfer by conduction from its base to the heat sink base plate and fins and then to the surrounding air. The mathematical model used here is based on the one that was derived in [21]. However, the studied structure is modified to include the wind speed variation that could be due to movement of vehicles on the road when this model is applied for pole mounted solar panel of a street lighting system. Design and selection of heat sink are also addressed in order to reduce the operating temperature of the solar cell. Therefore, the original study in [21] is extended here to provide the gained energy due to the proposed system of pole mounted solar panels by effective cooling using aluminum heat sink under hot weather and variable wind speed environment. 


\section{An Overview on Solar Panels}

A solar panel is a device by which light energy is converted into electrical energy. A brief description of solar panel structure and its principles are presented below.

\subsection{Solar Panel Structure}

Figure 1 shows the structure of solar panel considered in this study. It contains solar cells that consist of a p-n junction-based silicon layer encapsulated within a very thin film of protective sheets. These sheets are attached to both back and front sides, and are fabricated with ethyl vinyl acetate (EVA). Polyethylene terephthalate (PET) was used to fabricate the back sheet because if its high strength. This results in protection of the solar cells in addition to the junction box where the electrical output power connection terminals are located [22,23].

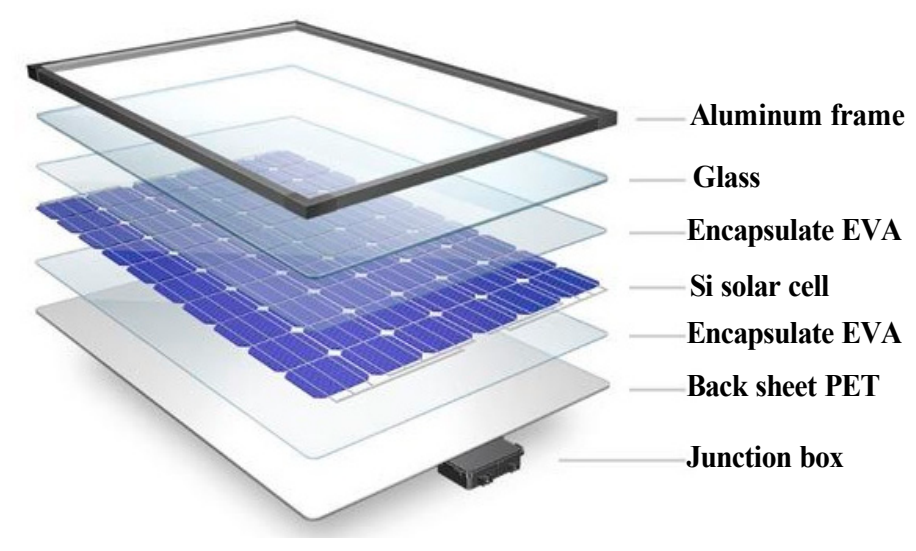

Figure 1. The material structure layers of a solar panel [22].

\subsection{Solar Cell Principle of Operation}

A solar cell is a p-n junction which is fabricated from silicon with few impurities. When the solar radiation strikes its surface, it forces the electrons to acquire enough energy so that electrons become free and an abundance of electron-hole pairs is created and a potential difference appears at the terminals. Then, an electric current flows if the circuit is connected to a load $[24,25]$ as shown in Figure 2.

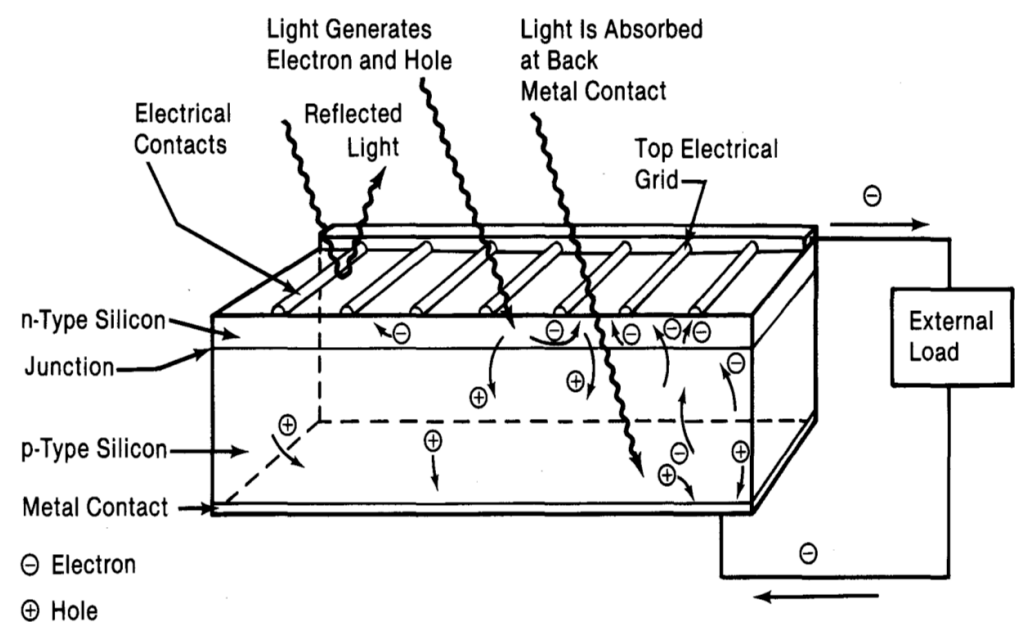

Figure 2. Principle of operation of a solar cell [24]. 


\section{Solar Cell Energy Transmitted Mathematical Model}

As sunlight falls on the surface of any solar cell, an amount of energy $Q_{C}$ is trasmitted through the glass surface [21,26-30] given by the following Equation (1):

$$
Q_{C}=f_{p} \alpha_{C} \tau_{g} S_{r} A
$$

Figure 3 shows a cross-section of the solar panel as well as its thermal resistance network. The solar energy irradiating the solar panel $Q_{C}$ is divided into two parts [21,31]; the useful energy and the thermal losses. The first part, i.e., the useful extracted energy, generates electrical energy $Q_{e l}$ according to the following expression:

$$
Q_{e l}=\eta_{e l} Q_{C}
$$

where $\eta_{e l}$ is the electrical efficiency given by:

$$
\eta_{e l}=\eta_{o}\left[1-\beta\left(T_{C}-T_{o}\right)\right]
$$

$\beta$ is the temperature coefficient that relies on the material type $\left(\beta=0.004 \mathrm{~K}^{-1}\right.$ for a monocrystalline solar cell fabricated from silicon [12,21]) and is given by Equation (4):

$$
\beta=\frac{1}{T_{C}^{*}-T_{o}}
$$

The nominal electrical efficiency $\eta_{o}$ under the Standard Test Conditions (STC) is given by the Equation (5):

$$
\eta_{o}=\frac{P_{m p p}}{Q_{C}}
$$

As mentioned in $[17,21]$, the $P_{m p p}$ is the output power $(\mathrm{W})$, that is tracked at the maximum power point (MPP), and given by Equation (6):

$$
P_{m p p}=V_{m p p} I_{m p p}=V_{O C} I_{S C} F F
$$

The second part is transformed into thermal energy losses $Q_{t h}$ that can be expressed as follows:

$$
Q_{t h}=\eta_{t h} Q_{C}
$$

where $\eta_{t h}$ is the thermal efficiency, given by:

$$
\eta_{t h}=\frac{U_{L}\left(T_{C}-T_{a}\right)}{f_{p} \alpha_{C} \tau_{g} S_{r}}
$$

where $U_{L}$ is the overall heat transfer coefficient, given by Equation (9):

$$
U_{L}=U_{t}+U_{b}+U_{e}
$$

where $U_{t}, U_{b}$ and $U_{e}$ are the heat transfer coefficients of top, bottom and edges, respectively, given in Equations (10)-(12):

$$
\begin{gathered}
U_{t}=\left(\frac{1}{R_{c d 1}+R_{c d 2}+\left(R_{c v 1} \| R_{r 1}\right)}\right) \\
U_{b}=\left(\frac{1}{R_{c d 3}+R_{c d 4}+\left(R_{c v 2} \| R_{r 2}\right)}\right) \\
U_{e}=\frac{A_{e}\left(k_{e} / t_{e}\right)}{A}
\end{gathered}
$$




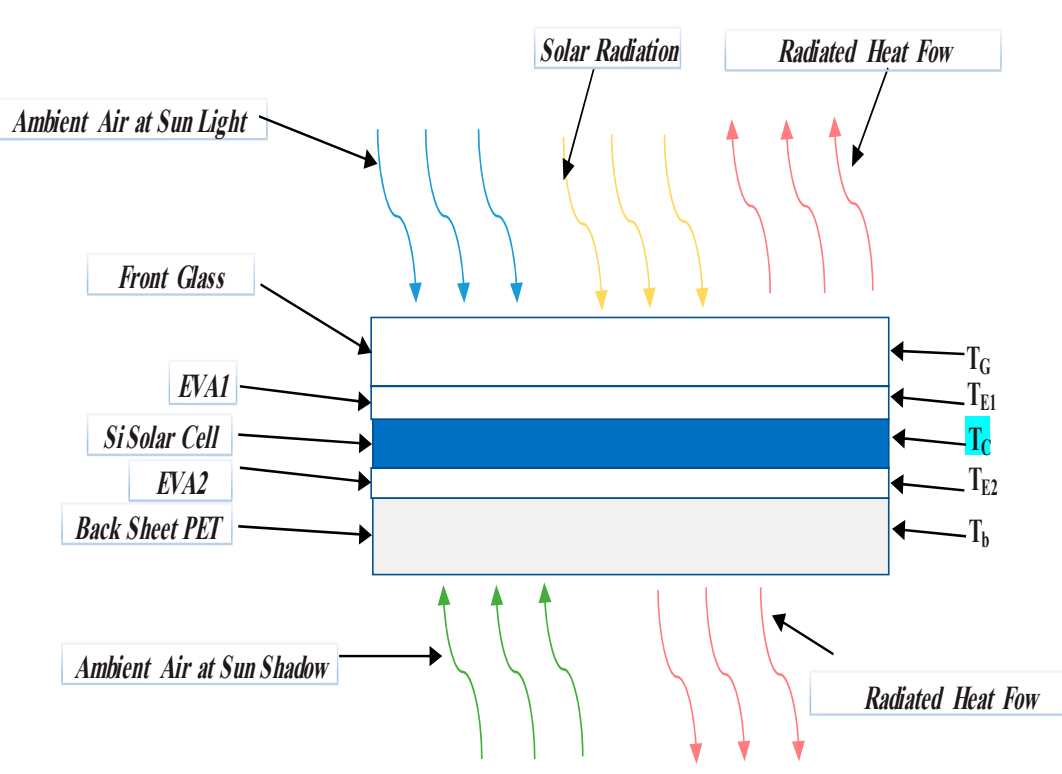

(a)

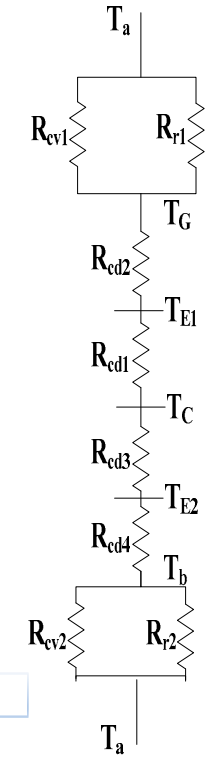

(b)

Figure 3. Solar panel (a) Cross-section (b) Thermal resistance network [21].

Table 1. Properties of the solar panel layers [21,23].

\begin{tabular}{cccccc}
\hline Layer Material & $\boldsymbol{t}(\mathbf{m m})$ & $\boldsymbol{k}(\mathbf{W} /(\mathbf{m} . \mathbf{K}))$ & $\boldsymbol{T}$ & $\boldsymbol{\alpha}$ & $\boldsymbol{\varepsilon}$ \\
\hline Glass & 4 & 0.78 & 0.90 & 0.02 & 0.91 \\
Ethyl vinyl acetate (EVA) & 0.4 & 0.34 & 0.97 & 0.03 & 0.85 \\
Monocrystalline silicon & 0.4 & 158.726 & - & 1 & 0.67 \\
Polyethylene terephthalate (PET) & 0.5 & 0.15 & - & 1 & 0.85 \\
Silicon grease & 0.5 & 2.2 & - & - & - \\
Aluminum & 0.5 & 239 & - & - & 0.90 \\
\hline
\end{tabular}

The properties of the layers are listed in Table 1, where the reflection coefficient of the glass $\zeta=0.1$, indicating the solar radiation reflected from the surface of the glass [23]. The thermal resistance of any layer is given by Equation (13) for conduction and by Equation (14) for convection or radiation [21,32-34]:

$$
\begin{gathered}
R_{c d}=\frac{t}{k A} \\
R_{c v, o r, r}=\frac{1}{h_{c v, o r, r} A}
\end{gathered}
$$

The heat transfer coefficient of back or front surfaces due to radiation effect $h_{r, f-a, o r, b-a}$ and the surrounding air heat transfer coefficient due to convection effect $h_{c, G-a, o r, b-a}$ are given by Equations (15)-(17):

$$
\begin{gathered}
h_{r, G-a, o r, b-a}=\frac{\sigma \varepsilon_{G, o r, b}\left(T_{G, o r, b}+T_{s}\right)\left(T_{G, o r, b}^{2}+T_{s}^{2}\right)\left(T_{G, o r, b}-T_{s}\right)}{\left(T_{G, o r, b}-T_{a}\right)} \\
h_{c v, G-a, o r, b-a}=h_{w}=5.74 \omega_{r}^{0.8} L_{c h}^{-0.2} \\
h_{c v, G-a, o r, b-a}=N u \frac{k_{a}}{L_{c h}}
\end{gathered}
$$

where $L_{c h}$ is the surface characteristic length [35] as given in Equation (18), $T_{\mathcal{S}}$ is the sky temperature that is calculated by the empirical Equation (19), $h_{w}$ is the convective heat transfer coefficient due to 
wind speed as defined in [36], $\left(\omega_{r}=4-15 \mathrm{~m} / \mathrm{s}\right)$ is the resultant wind speed due to the natural air wind speed $\left(\omega_{s}=4 \mathrm{~m} / \mathrm{s}\right)$ and the turbulence air $\left(\omega_{t}=0-11 \mathrm{~m} / \mathrm{s}\right)$ that is induced by movement of vehicles on the road as per Equations (20) and (21) as described in [21,37-40]:

$$
\begin{gathered}
L_{c h}=\frac{4 A}{p} \\
T_{s}=0.0552 T_{a}^{1.5} \\
\omega_{r}=\omega_{s}+\omega_{t} \\
\omega_{t}=\sqrt{\left(\frac{n_{v} C_{D} A_{f v} \omega_{v}^{3}}{2 c_{e} L_{v}}\right)^{\frac{2}{3}}}
\end{gathered}
$$

As per Equations (20) and (21), the turbulence due to vehicles motion on the road accelerates the wind speed, which contributes to solar panel temperature reduction. As mentioned in [31,35], Nu is a Nusselt number that is calculated by Equation (22):

$$
N u=0.664 \operatorname{Re}^{\frac{1}{2}} \operatorname{Pr}^{\frac{1}{2}}
$$

where Re is the Reynold number that is calculated using Equation (23) and $P r$ is the Prandtl number that is calculated using Equation (24):

$$
\begin{gathered}
R e=\frac{\rho \omega_{r} L_{c h}}{\mu} \\
\operatorname{Pr}=\frac{\mu}{\lambda}
\end{gathered}
$$

As shown in Figure 4, the heat transfer losses will be distributed in the top, bottom and edges directions [21,31,41] according to Equations (25)-(27) respectively:

$$
\begin{aligned}
& Q_{t}=U_{t} A\left(T_{C}-T_{a}\right) \\
& Q_{b}=U_{b} A\left(T_{C}-T_{a}\right) \\
& Q_{e}=U_{e} A_{e}\left(T_{C}-T_{a}\right)
\end{aligned}
$$

As mentioned in $[29,41,42]$, the solar cell operating temperature $\left({ }^{\circ} \mathrm{C}\right)$ is given by Equation $(28)$ :

$$
T_{C}=T_{a}+\frac{N O C T-20}{800} S_{r}
$$

where NOCT indicates the normal operating cell temperature as per the manufacturer's datasheet. Tthe solar cell temperature $T_{C}$ relies on the value of the solar radiation and the measured wind speed [43] as given by the empirical Equation (29):

$$
T_{C}=T_{a}+\left(S_{r} \cdot A\right) e^{-3.473-0.0594 \omega_{r}}
$$

To incorporate the effect of the wind speed on the convective heat transfer coefficient, a correlation shall be done in the cell temperature [31,43-46] for both Equations (28) and (29). Then, the solar cell temperature $T_{C}$ is given, respectively, in the following approximate and accurate expressions:

$$
\begin{gathered}
T_{C}=T_{a}+\frac{S_{r}}{S_{r, \text { NOCT }}}\left(T_{\text {NOCT }}-T_{a, \text { NOCT }}\right) \frac{9.5}{h_{w}}\left(1-\frac{\eta_{e l}}{\tau \alpha}\right) \\
T_{C}=T_{a}+\frac{S_{r}}{S_{r, \text { NOCT }}}\left(T_{\text {NOCT }}-T_{a, \text { NOCT }}\right) \frac{U_{L, N O C T}}{U_{L}}\left(1-\frac{\eta_{e l}}{\tau \alpha}\right)
\end{gathered}
$$


where $\tau \alpha=0.9, T_{a, N O C T}=20^{\circ} \mathrm{C}$ or $293 \mathrm{~K}, S_{r, N O C T}=800 \mathrm{~W} / \mathrm{m}^{2}, U_{L, N O C T}$ is the overall heat transfer coefficient at NOCT, wind speed is $1 \mathrm{~m} / \mathrm{s}$ at NOCT. The analysis of the absorbed solar energy by the solar panel shall follow the energy balance [21,31], as per Equation (32), where the sum of the electrical and thermal efficiencies is equal to unity:

$$
Q_{C}=Q_{e l}+Q_{t h}
$$

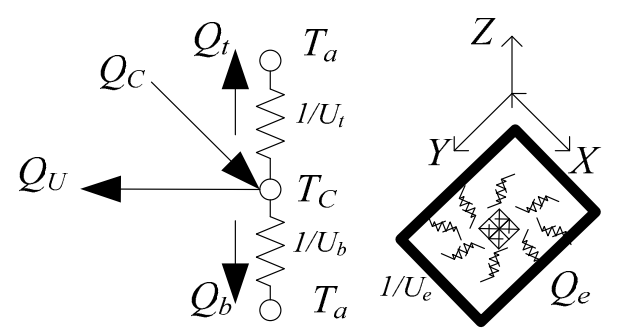

Figure 4. Equivalent thermal network of the solar panel (top, bottom and edge) [21].

\section{Solar Energy Electrical Model}

A single diode model of the solar cell is considered as the common electrical model, shown in Figure 5 for a solar panel that consists of $n_{c}$ solar cells. The mathematical model of a single diode solar cell is shown in Appendix A. The output power $P_{m p p}$ at the MPP is as given in Equation (6). Both the voltage and current at the MPP are calculated as mentioned in Appendix A by simultaneously and numerically solving Equations (A11) and (A12) or Equations (A13) and (A14) as in [21,24,30,31,47-50].

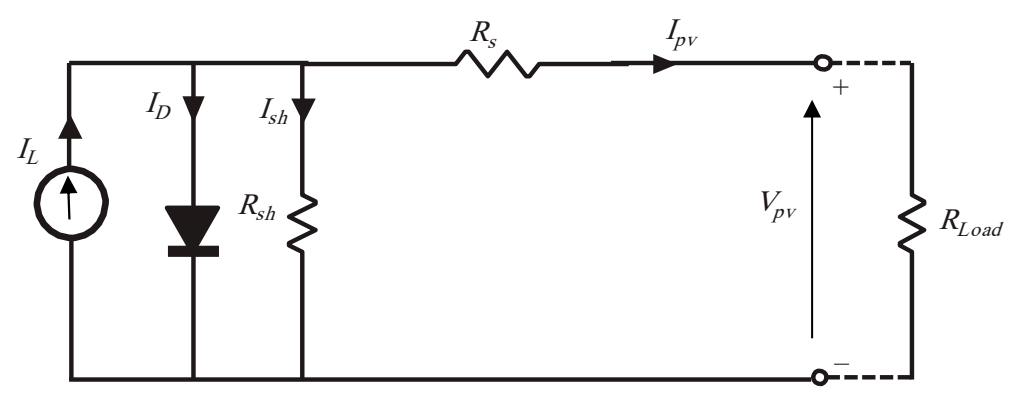

Figure 5. A single diode solar cell equivalent model [21].

\section{The Methodology of Temperature Mitigation}

The solar panel structure in this work is modified by installating an aluminum heat sink on its back sheet. First its shape will be selected and then its design will be performed. Finally, to obtain the experimental results, it will be assembled onto the solar panel back sheet.

\subsection{Design and Selection of Aluminum Heat Sink}

For this study, the heat sink is manufactured using aluminum and its shape is rectangular with length $L(\mathrm{~m})$, width $W(\mathrm{~m})$. It is connected by casting with $N$ number of fins as shown in Figure $6 \mathrm{a}$. The heat transfer from the source that has a temperature $T_{b}$ to the heat sink surface via interface like a thermal grease used to fill any partial space between the heat source and sink to improve the thermal conductivity. The thermal network for heat exchange includes conduction, convection and radiation with ambient air as shown in Figure $6 \mathrm{~b}[51,52]$. The lumped heat sink thermal resistance $R_{H s}$ is presented by Equation (33):

$$
R_{H s}=R_{i n r}+R_{c}+R_{s p}+R_{f i n s}+R_{f a}
$$




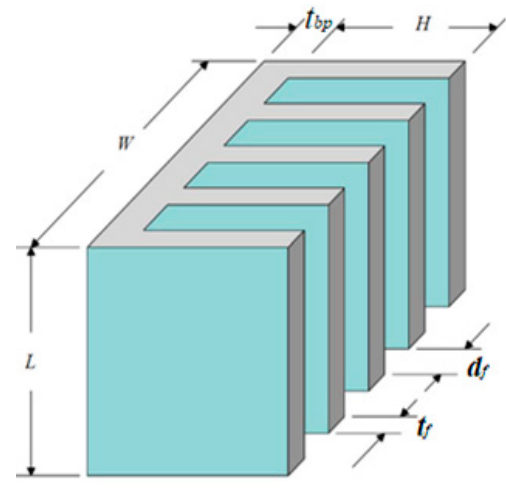

(a)

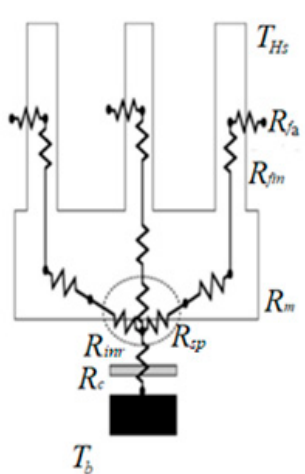

(b)

Figure 6. (a) Heat sink geometry, (b) Heat sink thermal resistance network [49].

The interface thermal resistance $R_{i n r}$ is given by Equation (13). It depends on the interface material conductivity $k_{r}(\mathrm{~W} / \mathrm{m} . \mathrm{K})$ and the surface area $A\left(\mathrm{~m}^{2}\right)$ and it is inversely proportional to its thickness $t_{r}(\mathrm{~mm})$ [52]. Also, the contact resistance $R_{c}$ between the heat source and the interface is given by Equation (13). It depends on the material properties and assembly method [51,53-56]. The spreading resistance is determined by the Equation (34):

$$
R_{s p}=\frac{\psi_{a v}}{\sqrt{\pi} k A}=\frac{1-1.410 \varepsilon_{r}+0.344 \varepsilon_{r}^{3}+0.043 \varepsilon_{r}^{5}+0.034 \varepsilon_{r}^{7}}{4 k \sqrt{A}}
$$

where $\psi_{a v}$ is the dimensionless spreading resistance that is calculated as described in [54]. The adiabatic thermal resistance per each fin is given by Equation (35):

$$
R_{f i n}=\frac{1}{\tanh (m H) \sqrt{h_{T} p_{f} k A_{f}}}
$$

where $m$ is the fin parameter that is defined as a heat transfer ratio between the heat transfer of a finite length fin and an infinite length fin at identical medium conditions and it is given by Equation (36). To minimize the error due to the dimensional fins when considering the thermal energy analysis [32], it is necessary to achieve $\left(h_{T} \cdot t_{f} / k<0.2\right)$ :

$$
m=\sqrt{\frac{h_{T} p}{k A_{f}}}
$$

The lumped thermal resistance of total number of fins $\left(N_{f}\right)$ can be calculated as a parallel circuit by Equation (37):

$$
R_{f i n s}=\frac{1}{N_{f} / R_{f i n}+\left(N_{f}-1\right) R_{b p b}}
$$

where $R_{b p b}$ is the thermal resistance of the back heat sink base plate, given by Equation (13). The thermal resistance $R_{f a}$ from the heat sink fins to ambient air is calculated by Equation (14) as a parallel convection and radiation thermal resistances. The total heat transfer rate $Q_{f T}$ from the heat sink fins surface is calculated by Equation (38):

$$
Q_{f T}=Q_{f i n s}+Q_{u n f i n s}=h_{T}\left(\eta_{f i n s} A_{\text {fins }}+A_{\text {unfins }}\right)\left(T_{H s}-T_{a}\right)
$$

For rectangular shape fins, the efficiency $\eta_{\text {fins }}$ is given by Equation (39):

$$
\eta_{\text {fins }}=\frac{\tanh (m H)}{m H}
$$


As mentioned in $[51,56]$, the optimum spacing $d_{f}$ between the fins is given by Equation $(40)$ :

$$
d_{f}=2.714 \frac{H}{\sqrt[4]{R_{a}}}
$$

where $R a$ is Rayleigh number that is equal to the multiplication of Prandtl number Pr and Grashoff number $G r$ as in Equation (41):

$$
R a=P r . G r=\frac{g \delta \Delta T_{m} L_{c h}^{3}}{\mu \lambda}
$$

where $T_{m}$ is the mean absorbed cell temperature as given in Equation (42), $\Delta T$ is the temperature difference between solar panel layers $(\mathrm{K})$ as in Equation (43):

$$
\begin{aligned}
T_{m} & =\frac{T_{C}+T_{G, o r, b}}{2} \\
\Delta T & =T_{C}-T_{G, o r, b}
\end{aligned}
$$

The optimum total number of fins $N_{f}$ is given by Equation (44):

$$
N_{f}=\frac{W-t_{f}}{d_{f}+t_{f}}+1
$$

The aluminum heat sink selection depends on Equations (13), (14) and (33)-(44), using the data of Table 1 and the solar module dimensions as listed in Table 2. Properties of the thermal grease that was used as an interface between the solar panel and the aluminum heat sink has been specified in Table 3. A computational MATLAB software program was used to calculate the required heat sink parameters that matched Figure $6 \mathrm{a}$, the obtained results as recorded in Table 4, where the aluminum thermal conductivity is equal to $239 \mathrm{~W} / \mathrm{m} . \mathrm{K}[57,58]$.

Table 2. Characteristics of the solar panel [21]. Standard Test Conditions (STC): Irradiance $1000 \mathrm{~W} / \mathrm{m}^{2}$, Module Temperature $25^{\circ} \mathrm{C}$, Air Mass 1.5 .

\begin{tabular}{ll}
\hline \multicolumn{1}{c}{ Parameters of Solar Module } & \multicolumn{1}{c}{ Values \& Units } \\
\hline Brand/Cell type & BLT/Monocrystalline \\
Maximum Power & $250 \mathrm{~W}$ \\
Power tolerance range & $\pm 3 \%$ \\
Module efficiency & $23.6 \%$ \\
Voltage at open circuit $V_{\text {o.c }}$ & $36.7 \mathrm{~V}$ \\
Current at short circuit $I_{S . C}$ & $9 \mathrm{~A}$ \\
Maximum power voltage $V_{m p}$ & $30.6 \mathrm{~V}$ \\
Maximum power current $I_{m p}$ & $8.17 \mathrm{~A}$ \\
Normal operating cell temperature $(\mathrm{NOCT})$ & $45 \pm 2{ }^{\circ} \mathrm{C}$ \\
Temperature Coefficient of $V_{o . c}$ & $-0.32 \% /{ }^{\circ} \mathrm{C}$ \\
Geometric (Length $\times$ Width $\times$ Hight) & $1646 \times 990 \times 45 \mathrm{~mm}$ \\
$n_{C}$ (number of solar cells in series) & 60 \\
$\alpha_{C}$ & 0.9 \\
$\tau_{g}$ & 0.95 \\
$f_{p}$ & 0.9 \\
\hline
\end{tabular}

\subsection{Assembly the Aluminum Heat Sink to the Solar Panel Back Sheet}

The aluminum heat sink is installed to the back sheet of the solar panel using a silicon thermal grease to fill any cavities. The objective of the aluminum heat sink is to reduce the adverse effects of any rise in temperature. The mechanical assembly is carried out by using screw bolts to ensure a tight contact between surfaces. Heat is dissipated by heat transfer and conduction from the solar panel back sheet to the surrounding air by convection and radiation as shown in Figure $7 \mathrm{a}$ and the thermal 
resistance diagram is shown in Figure $7 \mathrm{~b}$. As mentioned in [11], the thermal energy rating $Q_{r}$ that results from the air touching the surfaces of the solar panel because of the resultant wind speed is given by Equation (45):

$$
Q_{r}=m_{A} C_{A}\left(T_{m}-T_{a}\right)
$$

The procedure is described by the flowchart depicted in Figure 7c.

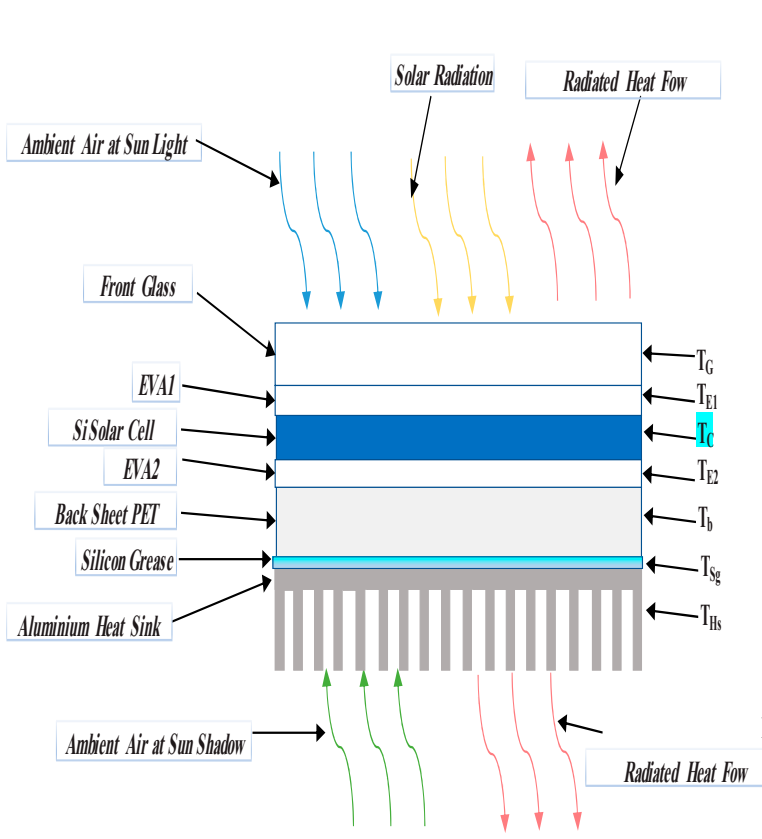

(a)

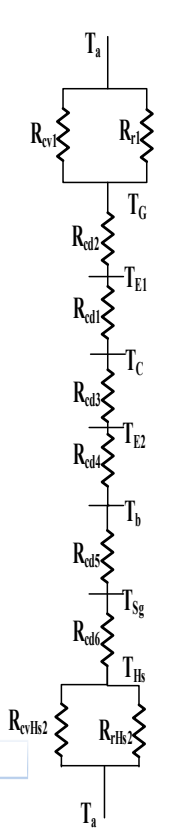

(b)

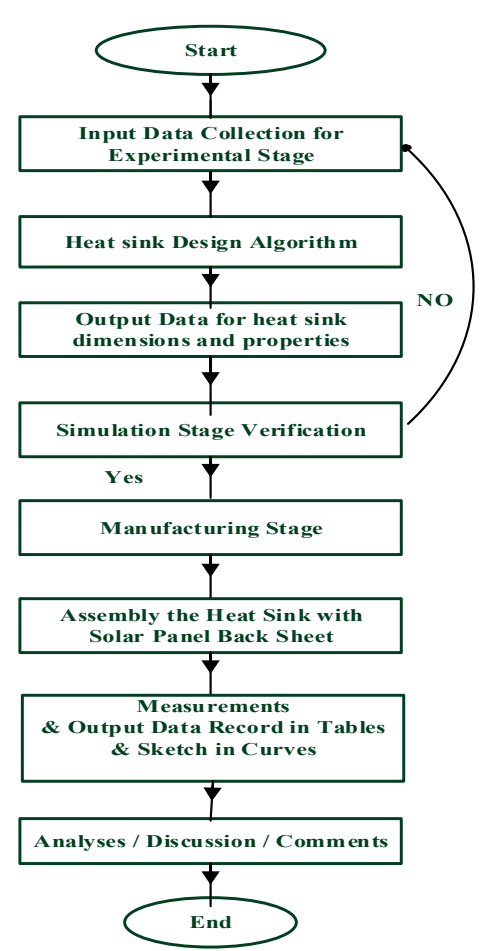

(c)

Figure 7. (a) Cross-section of the solar panel layers in conduction with aluminum heat sink, (b) Thermal resistance network of the solar panel layers, (c) Procedure description.

\section{Simulation Model}

The developed mathematical model is used to estimate the solar energy absorbed by the solar panel and perform the calculations of the temperatures of the solar cell, glass, and back sheet. Using this approach both the useful extracted electrical energy beside the thermal energy can also be calculated. The simulation model can be generated, for constant average ambient temperature and varying wind speeds when the average solar radiation is constant. The solar panel properties are given as in Table 2 . The location coordinates of King Abdulaziz University (KAU) situated in Jeddah, Saudi Arabia, are detailed in Table 3. The parameters of the solar radiation $S_{r}$ and the wind speed $\omega_{s}$ [59-61] were provided by the meteorological weather station as shown in Figure 8.

Table 3. Meteorological weather station parameters [21].

\begin{tabular}{ll}
\hline \multicolumn{1}{c}{ Weather Parameters } & \multicolumn{1}{c}{ Values \& Units } \\
\hline Latitude & $21.49604^{\circ}$ \\
Longitude & $39.24492^{\circ}$ \\
Elevation & $75 \mathrm{~m}$ \\
$S_{r}$ & $672 \mathrm{~W} / \mathrm{m}^{2}$ \\
$\omega_{s}$ & $4-7 \mathrm{~m} / \mathrm{s}$ \\
$\omega_{t}$ & $0-11 \mathrm{~m} / \mathrm{s}$ \\
$\omega_{r}$ & $4-18 \mathrm{~m} / \mathrm{s}$ \\
$T_{a}$ & $315 \mathrm{~K}$ \\
\hline
\end{tabular}


Table 4. Heat-sink selection parameters and properties.

\begin{tabular}{ll}
\hline Parameters of the Heat Sink & Values \& Units \\
\hline$L$ & $1646 \mathrm{~mm}$ \\
$W$ & $990 \mathrm{~mm}$ \\
$H$ & $40 \mathrm{~mm}$ \\
$t_{b p}$ & $0.5 \mathrm{~mm}$ \\
$t_{f}$ & $1.5 \mathrm{~mm}$ \\
$d_{f}$ & $25 \mathrm{~mm}$ \\
$N$ & 36 \\
Material & Aluminum $6101-\mathrm{T} 6$ \\
Aluminum composition in Alloy & $97 \%$ \\
Density & $2.70 \mathrm{~g} / \mathrm{cc}$ \\
Specific Heat Capacity & $0.895 \mathrm{~J} / \mathrm{g}-{ }^{\circ} \mathrm{C}$ \\
Thermal Conductivity & $239 \mathrm{~W} / \mathrm{m}-\mathrm{K}$ \\
Thermal resistance at natural convection & $0.56^{\circ} \mathrm{C} / \mathrm{W}$ \\
Thermal resistance at forced convection & $0.088^{\circ} \mathrm{C} / \mathrm{W}$ \\
Shear Strength & $138 \mathrm{MPa}$ \\
Ultimate Tensile Strength & $221 \mathrm{MPa}$ \\
\hline
\end{tabular}
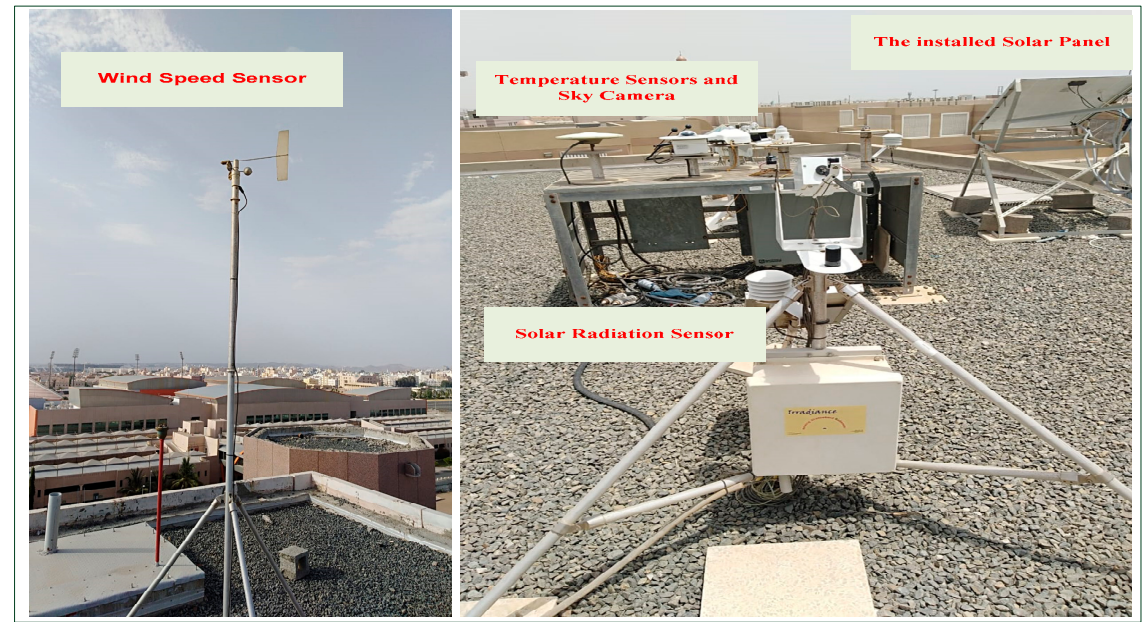

Figure 8. KAU meteorological weather station [21].

Simulation model is developed using computational program of MATLAB software, and simulation results are derived as follows:

\subsection{Simulation of Solar Panel without a Heat Sink}

This model describes the analysis of solar energy absorbed by the solar panel as shown in Figure 3. A computational MATLAB software program is run to calculate the temperatures of solar cells, glass, and back sheet as well as for calculating both the extracted electrical energy and the thermal energy including top, bottom and edge losses. The results are depicted in Tables 5-7 for various wind speeds $\left(\omega_{r}=1-15 \mathrm{~m} / \mathrm{s}\right)$.

Simulation results for the electrical characteristics without heat sink are presented in Table 8. 
Table 5. Temperatures of layers at various wind speeds for the simulation model without heat sink $\left(T_{a}=315 \mathrm{~K}\right)$.

\begin{tabular}{cccccc}
\hline$\omega_{r}(\mathbf{m} / \mathbf{s})$ & $T_{G}(\mathbf{K})$ & $T_{E V A g}(\mathrm{~K})$ & $T_{C}(\mathbf{K})$ & $T_{E V A b}(\mathbf{K})$ & $T_{b}(\mathbf{K})$ \\
\hline 1 & 338.88 & 340.69 & 341.11 & 340.69 & 339.50 \\
2 & 327.76 & 329.09 & 329.39 & 329.07 & 328.15 \\
3 & 323.68 & 324.82 & 325.08 & 324.79 & 323.96 \\
4 & 321.51 & 322.54 & 322.78 & 322.51 & 321.73 \\
5 & 320.16 & 321.12 & 321.33 & 321.07 & 320.32 \\
6 & 319.23 & 320.13 & 320.33 & 320.08 & 319.35 \\
7 & 318.55 & 319.40 & 319.59 & 319.34 & 318.63 \\
8 & 318.04 & 318.84 & 319.02 & 318.78 & 318.07 \\
9 & 317.63 & 318.39 & 318.57 & 318.32 & 317.63 \\
10 & 317.29 & 318.03 & 318.20 & 317.96 & 317.26 \\
11 & 317.02 & 317.73 & 317.89 & 317.65 & 316.96 \\
12 & 316.79 & 317.47 & 317.63 & 317.39 & 316.70 \\
13 & 316.60 & 317.25 & 317.40 & 317.16 & 316.48 \\
14 & 316.43 & 317.06 & 317.21 & 316.97 & 316.29 \\
15 & 316.28 & 316.89 & 317.03 & 316.79 & 316.12 \\
\hline
\end{tabular}

Table 6. Heat transfer coefficients at varying wind speeds for the simulation model without heat sink.

\begin{tabular}{|c|c|c|c|c|c|c|c|}
\hline$\omega_{r}(\mathrm{~m} / \mathrm{s})$ & $h_{w}\left(\mathrm{~W} / \mathrm{m}^{2} . \mathrm{K}\right)$ & $h_{r g}\left(\mathrm{~W} / \mathrm{m}^{2} . \mathrm{K}\right)$ & $h_{r b}\left(\mathrm{~W} / \mathrm{m}^{2} . \mathrm{K}\right)$ & $U_{t}(\mathrm{~W} / \mathrm{K})$ & $U_{b}\left(\mathrm{~W} / \mathrm{m}^{2} . \mathrm{K}\right)$ & $U_{e}\left(\mathrm{~W} / \mathrm{m}^{2} . \mathrm{K}\right)$ & $\eta_{e l} \%$ \\
\hline 1 & 5.50 & 9.27 & 7.98 & 13.51 & 12.71 & 0.08 & 12.74 \\
\hline 2 & 9.58 & 10.68 & 8.58 & 17.97 & 16.79 & 0.08 & 13.47 \\
\hline 3 & 13.25 & 12.35 & 9.30 & 22.05 & 20.47 & 0.08 & 13.73 \\
\hline 4 & 16.68 & 14.15 & 10.02 & 25.82 & 23.83 & 0.08 & 13.87 \\
\hline 5 & 19.94 & 16.07 & 10.72 & 29.35 & 26.94 & 0.08 & 13.96 \\
\hline 6 & 23.07 & 18.12 & 11.40 & 32.70 & 29.84 & 0.08 & 14.02 \\
\hline 7 & 26.10 & 20.31 & 12.06 & 35.90 & 32.56 & 0.07 & 14.07 \\
\hline 8 & 29.05 & 22.64 & 12.70 & 38.98 & 35.13 & 0.07 & 14.10 \\
\hline 9 & 31.92 & 25.14 & 13.33 & 41.96 & 37.57 & 0.07 & 14.13 \\
\hline 10 & 34.72 & 27.81 & 13.94 & 44.85 & 39.90 & 0.07 & 14.16 \\
\hline 11 & 37.47 & 30.68 & 14.53 & 47.67 & 42.12 & 0.07 & 14.17 \\
\hline 12 & 40.17 & 33.77 & 15.11 & 50.43 & 44.25 & 0.07 & 14.19 \\
\hline 13 & 42.83 & 37.09 & 15.69 & 53.14 & 46.30 & 0.07 & 14.20 \\
\hline 14 & 45.45 & 40.68 & 16.25 & 55.82 & 48.26 & 0.07 & 14.22 \\
\hline 15 & 48.03 & 44.55 & 16.80 & 58.46 & 50.16 & 0.07 & 14.23 \\
\hline
\end{tabular}

Table 7. Solar energy transmitted to the solar panel without heat sink (generated by the simulation model).

\begin{tabular}{cccccc}
\hline$\omega_{r}(\mathbf{m} / \mathbf{s})$ & $Q_{e l}(\mathbf{W})$ & $Q_{t}(\mathbf{W})$ & $Q_{b}(\mathbf{W})$ & $Q_{e}(\mathbf{W})$ & $Q(\mathbf{W})$ \\
\hline 1 & 112.63 & 430.87 & 436.25 & 2.20 & 981.95 \\
2 & 119.01 & 417.49 & 444.22 & 1.23 & 981.95 \\
3 & 121.36 & 406.89 & 452.84 & 0.87 & 981.95 \\
4 & 122.61 & 397.43 & 461.24 & 0.68 & 981.95 \\
5 & 123.40 & 388.65 & 469.35 & 0.56 & 981.95 \\
6 & 123.94 & 380.35 & 477.19 & 0.48 & 981.95 \\
7 & 124.34 & 372.42 & 484.78 & 0.42 & 981.95 \\
8 & 124.65 & 364.78 & 492.15 & 0.37 & 981.95 \\
9 & 124.90 & 357.39 & 499.33 & 0.33 & 981.95 \\
10 & 125.10 & 350.21 & 506.34 & 0.30 & 981.95 \\
11 & 125.27 & 343.22 & 513.19 & 0.28 & 981.95 \\
12 & 125.41 & 336.39 & 519.89 & 0.26 & 981.95 \\
13 & 125.54 & 329.71 & 526.46 & 0.24 & 981.95 \\
14 & 125.64 & 323.17 & 532.91 & 0.22 & 981.95 \\
15 & 125.74 & 316.76 & 539.25 & 0.21 & 981.95 \\
\hline
\end{tabular}


Table 8. Solar panel electrical characteristics without heat sink (generated using the simulation model).

\begin{tabular}{cccccccc}
\hline$\omega_{\boldsymbol{r}}(\mathbf{m} / \mathbf{s})$ & $\boldsymbol{V}_{\boldsymbol{o c}}(\mathbf{V})$ & $\boldsymbol{V}_{\boldsymbol{m p p}}(\mathbf{V})$ & $\boldsymbol{I}_{\boldsymbol{s c}}(\mathbf{A})$ & $\boldsymbol{I}_{\boldsymbol{m} p \boldsymbol{p}}(\mathbf{A})$ & $\boldsymbol{P}_{\boldsymbol{m p p}}(\mathrm{W})$ & $\boldsymbol{F F}$ & $\boldsymbol{\eta}_{\boldsymbol{l l}} \%$ \\
\hline 1 & 31.52 & 24.47 & 7.72 & 4.58 & 112.07 & 0.46 & 12.68 \\
2 & 32.89 & 27.57 & 7.68 & 4.30 & 118.46 & 0.47 & 13.40 \\
3 & 33.40 & 28.69 & 7.66 & 4.21 & 120.81 & 0.47 & 13.67 \\
4 & 33.67 & 29.26 & 7.65 & 4.17 & 122.06 & 0.47 & 13.81 \\
5 & 33.84 & 29.61 & 7.65 & 4.15 & 122.85 & 0.47 & 13.90 \\
6 & 33.96 & 29.83 & 7.64 & 4.14 & 123.39 & 0.48 & 13.96 \\
7 & 34.05 & 29.99 & 7.64 & 4.13 & 123.80 & 0.48 & 14.01 \\
8 & 34.11 & 30.10 & 7.64 & 4.12 & 124.11 & 0.48 & 14.04 \\
9 & 34.17 & 30.18 & 7.64 & 4.12 & 124.35 & 0.48 & 14.07 \\
10 & 34.21 & 30.23 & 7.64 & 4.12 & 124.56 & 0.48 & 14.09 \\
11 & 34.25 & 30.27 & 7.63 & 4.12 & 124.72 & 0.48 & 14.11 \\
12 & 34.28 & 30.29 & 7.63 & 4.12 & 124.87 & 0.48 & 14.13 \\
13 & 34.30 & 30.31 & 7.63 & 4.12 & 124.99 & 0.48 & 14.14 \\
14 & 34.33 & 30.31 & 7.63 & 4.13 & 125.10 & 0.48 & 14.16 \\
15 & 34.35 & 30.31 & 7.63 & 4.13 & 125.19 & 0.48 & 14.17 \\
\hline
\end{tabular}

\subsection{Simulation of Solar Panel with an Aluminum Heat Sink}

This model describes the analysis of solar energy absorbed to the solar panel with the aluminum heat sink. The heat is dissipated by conduction with the solar panel back sheet via thermal grease, the properties of which are enumerated in Table 9. A computational MATLAB software program was run to calculate the temperatures of solar cell, glass, and back sheet. Also, both the salutary electrical energy and the thermal energy including top, bottom and edge losses were calculated by the same program.

The results are listed in Tables 10-12 for various wind speeds $\left(\omega_{r}=1-15 \mathrm{~m} / \mathrm{s}\right)$. The results indicate that the temperature of the solar cell is decreased and the heat transfer through the solar panel bottom is increased due to the installation of the aluminum heat sink. The more wind speed increases the more temperature decreases. Table 13 presents simulation results for the solar panel electrical characteristics with the aluminum heat sink. When wind speed increases, temperature decreases and therefore the electrical efficiency improves and the extracted power increases.

Table 9. Thermal grease properties.

\begin{tabular}{ll}
\hline Parameters of the Thermal Grease & \multicolumn{1}{c}{ Values \& Units } \\
\hline Brand & GD 380 Thermal Paste \\
Colour & Gray \\
Specific gravity & $2.5 \mathrm{G} / \mathrm{Cc}$ \\
Thermal conductivity & $2.2 \mathrm{~W} / \mathrm{m} . \mathrm{K}$ \\
Operating temperature & $-50 \sim 200{ }^{\circ} \mathrm{C}$ \\
\hline
\end{tabular}

Table 10. Layers temperature at various wind speed for the simulation model with an aluminum heat $\operatorname{sink}\left(T_{a}=315 \mathrm{~K}\right)$.

\begin{tabular}{ccccccc}
\hline$\omega_{r}(\mathbf{m} / \mathbf{s})$ & $\boldsymbol{T}_{G}(\mathbf{K})$ & $T_{E V A g}(\mathbf{K})$ & $T_{C}(\mathbf{K})$ & $T_{E V A b}(\mathbf{K})$ & $T_{b}(\mathbf{K})$ & $T_{H s}(\mathbf{K})$ \\
\hline 1 & 328.61 & 329.97 & 330.29 & 330.09 & 329.55 & 329.55 \\
2 & 321.99 & 323.05 & 323.29 & 323.10 & 322.57 & 322.57 \\
3 & 319.57 & 320.49 & 320.70 & 320.51 & 319.98 & 319.98 \\
4 & 318.30 & 319.12 & 319.31 & 319.13 & 318.60 & 318.60 \\
5 & 317.51 & 318.27 & 318.44 & 318.25 & 317.72 & 317.72 \\
6 & 316.97 & 317.68 & 317.84 & 317.65 & 317.12 & 317.12 \\
7 & 316.59 & 317.24 & 317.39 & 317.20 & 316.67 & 316.67 \\
8 & 316.29 & 316.91 & 317.05 & 316.86 & 316.32 & 316.32 \\
9 & 316.07 & 316.64 & 316.77 & 316.58 & 316.04 & 316.04 \\
10 & 315.88 & 316.42 & 316.55 & 316.36 & 315.82 & 315.82 \\
11 & 315.73 & 316.24 & 316.36 & 316.17 & 315.63 & 315.63 \\
12 & 315.61 & 316.09 & 316.20 & 316.01 & 315.47 & 315.47 \\
13 & 315.51 & 315.96 & 316.06 & 315.87 & 315.33 & 315.33 \\
14 & 315.42 & 315.85 & 315.94 & 315.75 & 315.20 & 315.20 \\
15 & 315.35 & 315.75 & 315.84 & 315.65 & 315.10 & 315.10 \\
\hline
\end{tabular}


Table 11. Heat transfer coefficients at various wind speeds for the simulation model with aluminum heat sink.

\begin{tabular}{|c|c|c|c|c|c|c|c|}
\hline$\omega_{r}(\mathrm{~m} / \mathrm{s})$ & $h_{w}\left(\mathrm{~W} / \mathrm{m}^{2} \cdot \mathrm{K}\right)$ & $h_{r g}\left(\mathrm{~W} / \mathrm{m}^{2} \cdot \mathrm{K}\right)$ & $h_{r H s}\left(\mathrm{~W} / \mathrm{m}^{2} \cdot \mathrm{K}\right)$ & $U_{t}(\mathrm{~W} / \mathrm{K})$ & $U_{H s}\left(\mathrm{~W} / \mathrm{m}^{2} \cdot \mathrm{K}\right)$ & $U_{e}\left(\mathrm{~W} / \mathrm{m}^{2} . \mathrm{K}\right)$ & $\eta_{e l} \%$ \\
\hline 2 & 15.78 & 13.66 & 1.03 & 24.82 & 15.51 & 0.08 & 13.84 \\
\hline 4 & 27.47 & 21.36 & 1.28 & 37.34 & 25.15 & 0.07 & 14.09 \\
\hline 5 & 32.84 & 25.99 & 1.40 & 42.91 & 29.24 & 0.07 & 14.14 \\
\hline 6 & 37.99 & 31.25 & 1.50 & 48.20 & 33.00 & 0.07 & 14.18 \\
\hline 8 & 47.82 & 44.24 & 1.71 & 58.25 & 39.73 & 0.07 & 14.23 \\
\hline 9 & 52.55 & 52.31 & 1.81 & 63.13 & 42.77 & 0.07 & 14.24 \\
\hline 10 & 57.17 & 61.76 & 1.90 & 67.97 & 45.64 & 0.07 & 14.26 \\
\hline 11 & 61.70 & 72.94 & 1.99 & 72.82 & 48.35 & 0.07 & 14.27 \\
\hline 12 & 66.15 & 86.32 & 2.08 & 77.74 & 50.92 & 0.07 & 14.28 \\
\hline 13 & 70.52 & 102.56 & 2.17 & 82.77 & 53.36 & 0.07 & 14.29 \\
\hline
\end{tabular}

Table 12. Solar energy transmitted to the solar panel with aluminum heat sink (generated from the simulation model).

\begin{tabular}{cccccc}
\hline$\omega_{r}(\mathbf{m} / \mathbf{s})$ & $Q_{e l}(\mathrm{~W})$ & $Q_{t}(\mathrm{~W})$ & $Q_{H s}(\mathrm{~W})$ & $Q_{e}(\mathrm{~W})$ & $Q(\mathrm{~W})$ \\
\hline 1 & 118.52 & 252.90 & 609.22 & 1.31 & 981.95 \\
2 & 122.33 & 213.30 & 645.60 & 0.73 & 981.95 \\
3 & 123.74 & 192.10 & 665.61 & 0.51 & 981.95 \\
4 & 124.50 & 176.92 & 680.14 & 0.40 & 981.95 \\
5 & 124.97 & 164.72 & 691.94 & 0.33 & 981.95 \\
6 & 125.30 & 154.33 & 702.05 & 0.28 & 981.95 \\
7 & 125.54 & 145.17 & 711.00 & 0.24 & 981.95 \\
8 & 125.73 & 136.92 & 719.09 & 0.21 & 981.95 \\
9 & 125.88 & 129.38 & 726.50 & 0.19 & 981.95 \\
10 & 126.00 & 122.41 & 733.37 & 0.18 & 981.95 \\
11 & 126.10 & 115.91 & 739.77 & 0.16 & 981.95 \\
12 & 126.19 & 109.83 & 745.79 & 0.15 & 981.95 \\
13 & 126.27 & 104.09 & 751.45 & 0.14 & 981.95 \\
14 & 126.33 & 98.67 & 756.82 & 0.13 & 981.95 \\
15 & 126.39 & 93.52 & 761.92 & 0.12 & 981.95 \\
\hline
\end{tabular}

Table 13. Electrical characteristics of the solar panel for the simulation model with aluminum heat sink.

\begin{tabular}{cccccccc}
\hline$\omega_{\boldsymbol{r}}(\mathbf{m} / \mathbf{s})$ & $\boldsymbol{V}_{\boldsymbol{o c}}(\mathrm{V})$ & $\boldsymbol{V}_{\boldsymbol{m p p}}(\mathrm{V})$ & $\boldsymbol{I}_{\boldsymbol{s c}}(\mathrm{A})$ & $\boldsymbol{I}_{\boldsymbol{m p p}}(\mathrm{A})$ & $\boldsymbol{P}_{\boldsymbol{m p p}}(\mathbf{W})$ & $\boldsymbol{F F}$ & $\eta_{\boldsymbol{e l}} \%$ \\
\hline 1 & 32.91 & 27.65 & 7.67 & 4.29 & 118.52 & 0.47 & 13.41 \\
2 & 33.73 & 29.48 & 7.65 & 4.15 & 122.33 & 0.47 & 13.84 \\
3 & 34.03 & 30.13 & 7.64 & 4.11 & 123.74 & 0.48 & 14.00 \\
4 & 34.20 & 30.46 & 7.64 & 4.09 & 124.50 & 0.48 & 14.09 \\
5 & 34.30 & 30.65 & 7.63 & 4.08 & 124.97 & 0.48 & 14.14 \\
6 & 34.37 & 30.77 & 7.63 & 4.07 & 125.30 & 0.48 & 14.18 \\
7 & 34.42 & 30.85 & 7.63 & 4.07 & 125.54 & 0.48 & 14.21 \\
8 & 34.46 & 30.90 & 7.63 & 4.07 & 125.73 & 0.48 & 14.23 \\
9 & 34.50 & 30.93 & 7.63 & 4.07 & 125.88 & 0.48 & 14.24 \\
10 & 34.52 & 30.94 & 7.63 & 4.07 & 126.00 & 0.48 & 14.26 \\
11 & 34.54 & 30.95 & 7.63 & 4.07 & 126.10 & 0.48 & 14.27 \\
12 & 34.56 & 30.95 & 7.62 & 4.08 & 126.19 & 0.48 & 14.28 \\
13 & 34.58 & 30.94 & 7.62 & 4.08 & 126.27 & 0.48 & 14.29 \\
14 & 34.59 & 30.92 & 7.62 & 4.09 & 126.33 & 0.48 & 14.29 \\
15 & 34.60 & 30.90 & 7.62 & 4.09 & 126.39 & 0.48 & 14.30 \\
\hline
\end{tabular}




\subsection{Comparison of Results of the Two Simulation Models}

This section discusses the comparison of results of the two simulation models, without heat sink and with aluminum heat sink. The aluminum heat sink which is installed to the solar panel back sheet via thermal grease improves the thermal conductivity and appears to be effective at lowering the temperature. The aluminum heat sink causes a decrease in the thermal resistance of the bottom surface of the solar panel, which is equal to the inverse value of the heat transfer coefficient. When the aluminum heat sink is installed, the heat transfer through the bottom surface is increased, as shown in Figures 9 and 10, leading to a decrease in the solar cell temperature for similar weather conditions and wind speed where the the thermal losses are decreased and the extracted power is increased. The average ambient temperature is $\left(T_{a}=315 \mathrm{~K}\right)$ for this research, and the location is Jeddah, the coordinates for which have been given in Table 3. Jeddah is situated near the Equator and has hot weather during most parts of the year. The aluminum heat sink installation reduces the solar cell temperature which enhances the solar panel electrical characteristics. Thanks to the aluminum heat sink, the temperature and the thermal losses are decreased and the resulting average voltage drop is also decreased, then the solar panel open circuit and the MPP voltages $V_{o c}$ and $V_{m p p}$ are increased as shown in Figure 11. Also, the solar panel short circuit and the MPP currents $I_{s c}$ and $I_{m p p}$ are increased as shown in Figure 12. Consequently, the maximum power point is increased and the accumulative energy per day is increased.

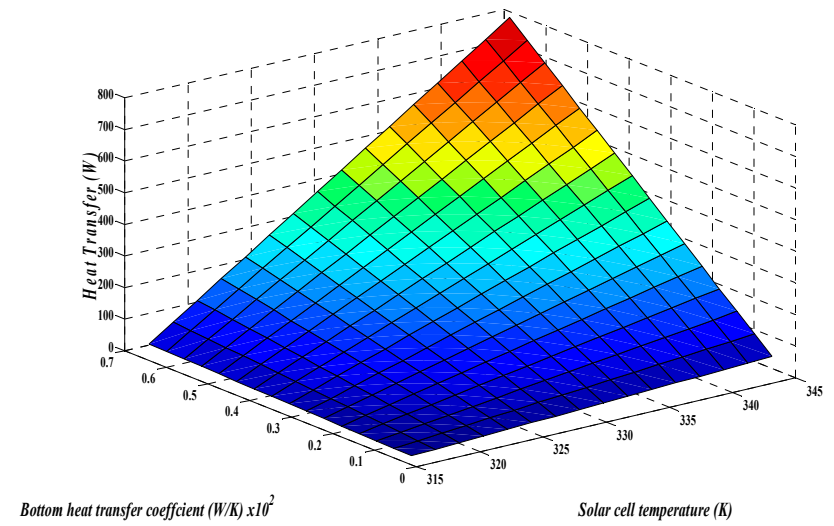

Figure 9. Increase in bottom heat transfer with solar cell temperature reduction due to installation of the aluminum heat sink.

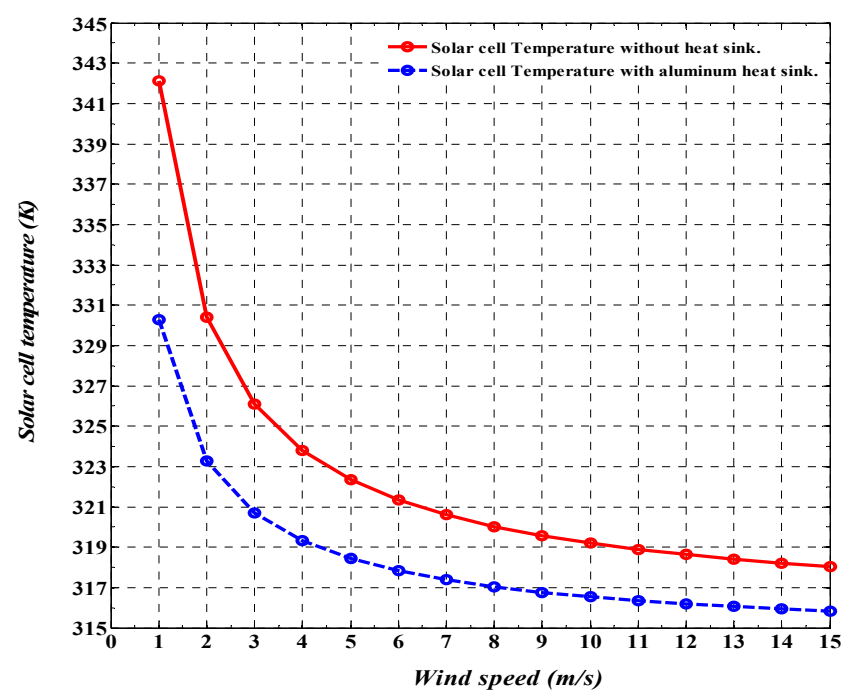

Figure 10. Solar cell temperature for various wind speeds with and without installation of the aluminum heat sink. 


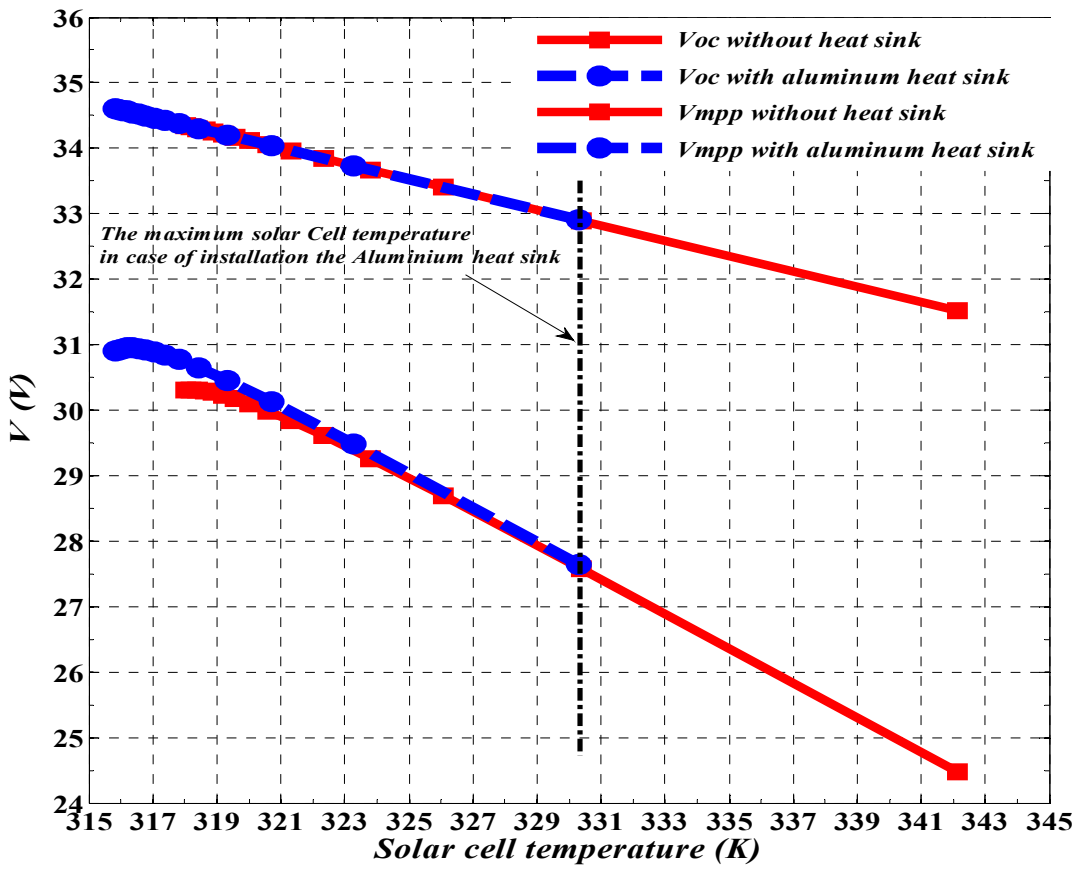

Figure 11. Electrical parameters of the solar cell: Open circuit voltage and MPP voltage variations at different solar cell temperatures.

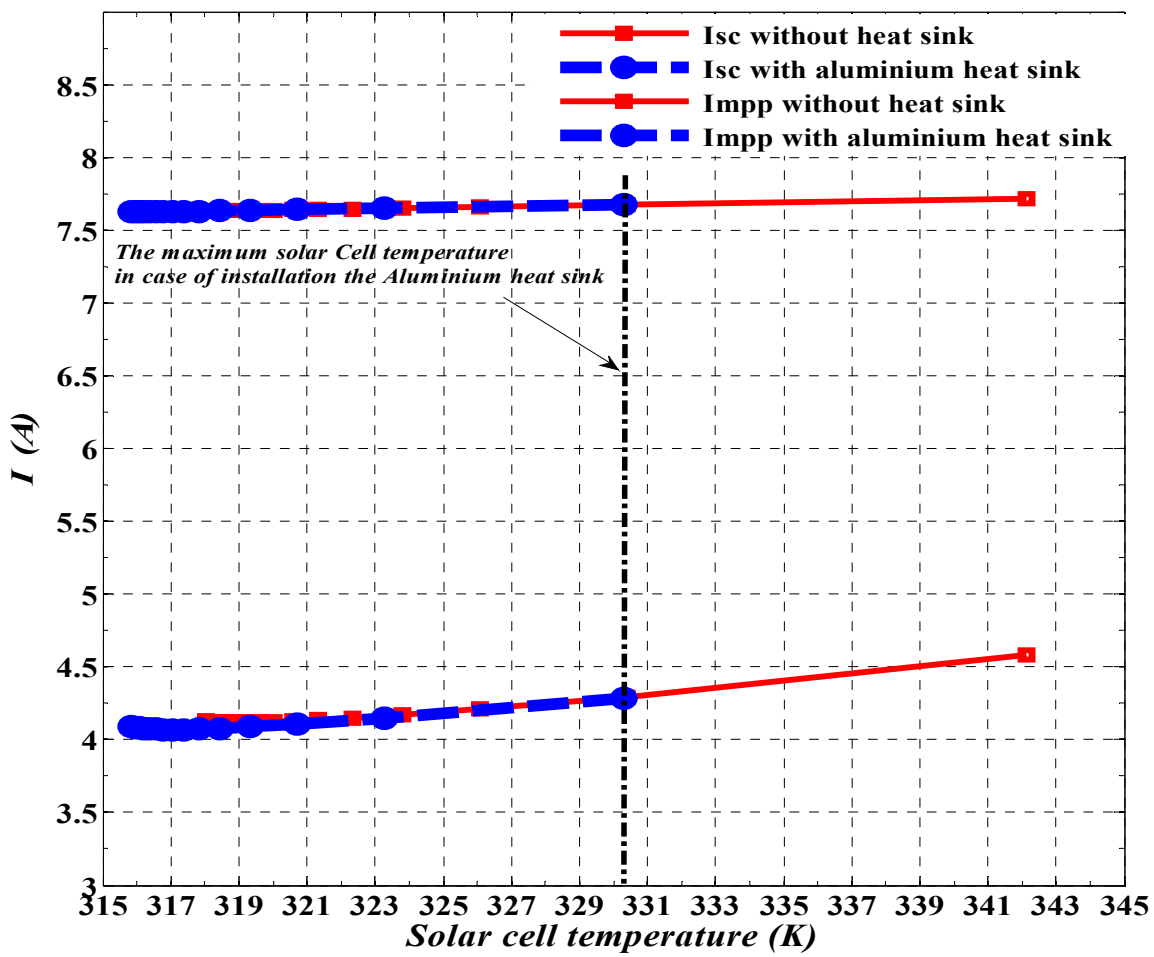

Figure 12. Electrical parameters of the solar cell: Short circuit current and MPP current at different solar cell temperatures.

It is clear that reduction in the solar cell temperature reduction has enhanced the electrical efficiency. This results are shown in Figure 13. Also, Figure 14 indicates that solar panel maximum output power is also increased. 


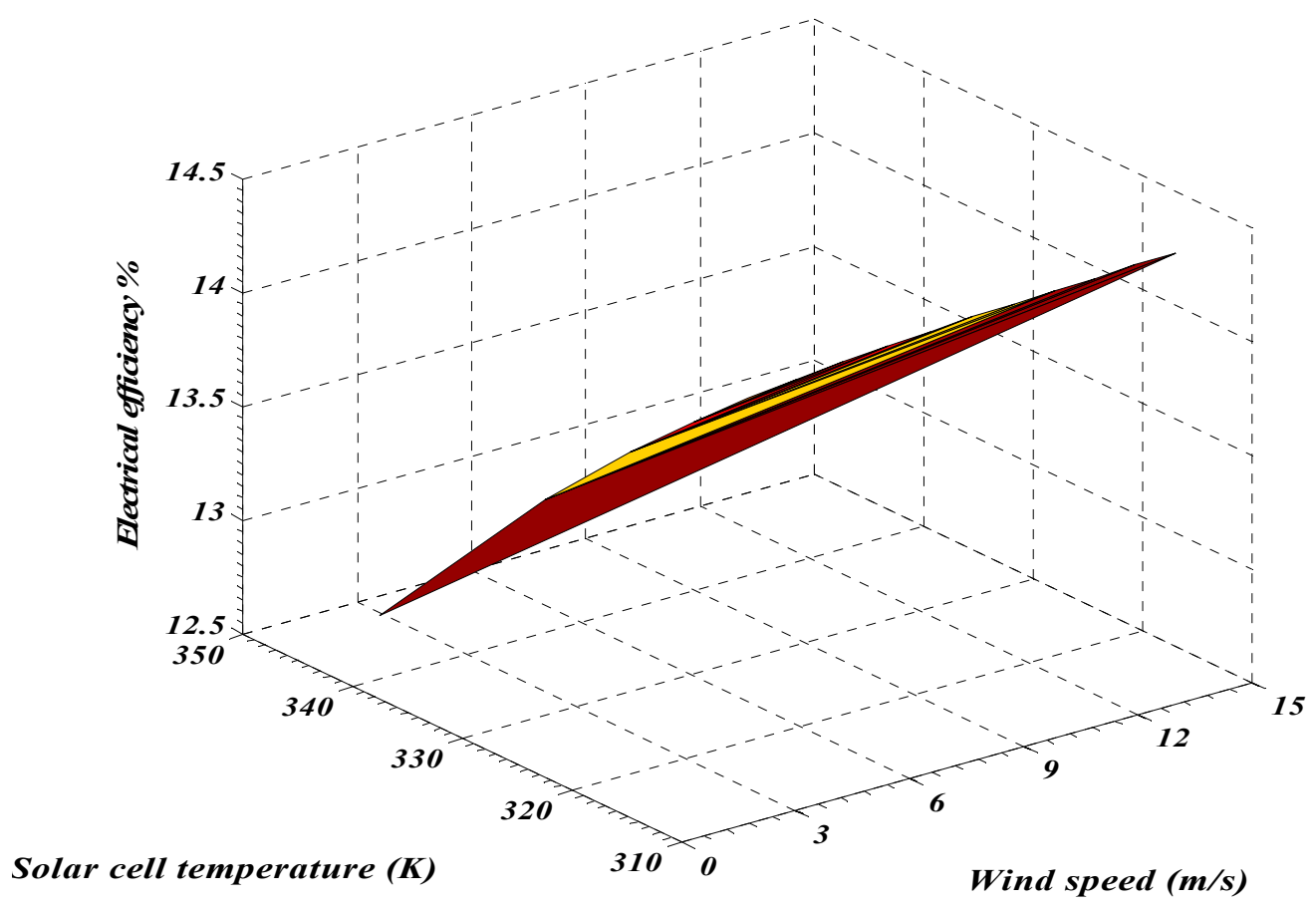

Figure 13. Three-dimentional graph of the solar panel perforamce: Efficiency, temperature and wind speeds.

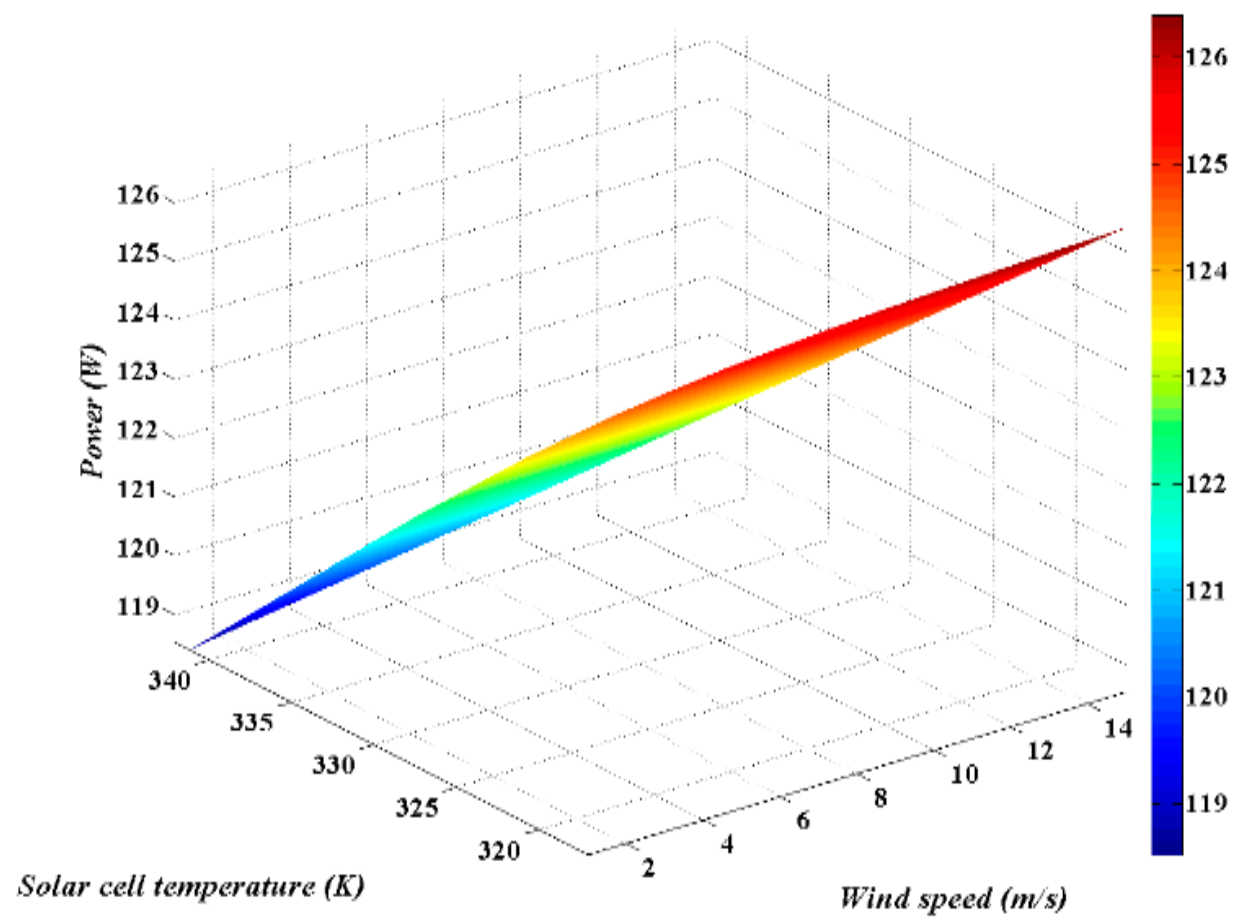

Figure 14. Three-dimentional graph of the solar panel perforamce: Output power at different temperature and wind speeds.

\section{The Experimental Setup Models}

The experimental setup model is implemented as per the schematic diagram shown in Figure 15. This setup uses a 250-Watt solar panel to charge 200 Ah deep cycle gel battery via 30 A MPPT solar charger controller. The battery is used to energize a 84-watt street lighting fixture. As per the Saudi Arabian General Authority of Meteorology and Environmental Protection [62], as well as the 
data obtained from King Abdulaziz University (KAU) weather station, which is shown in Figure 8, the highest ambient temperature is observed during summer season in June, so this study was conducted under June climatic conditions to study the effect of maximum temperature on the solar panel performance. The solar panel was installed at a fixed tilt angle $\left(\theta=25^{\circ}\right)$, orientation south, sloped by azimuth angle $\left(\phi=10^{\circ}\right)$ towards the west direction. The details of the set up as well as the results are presented as follows.

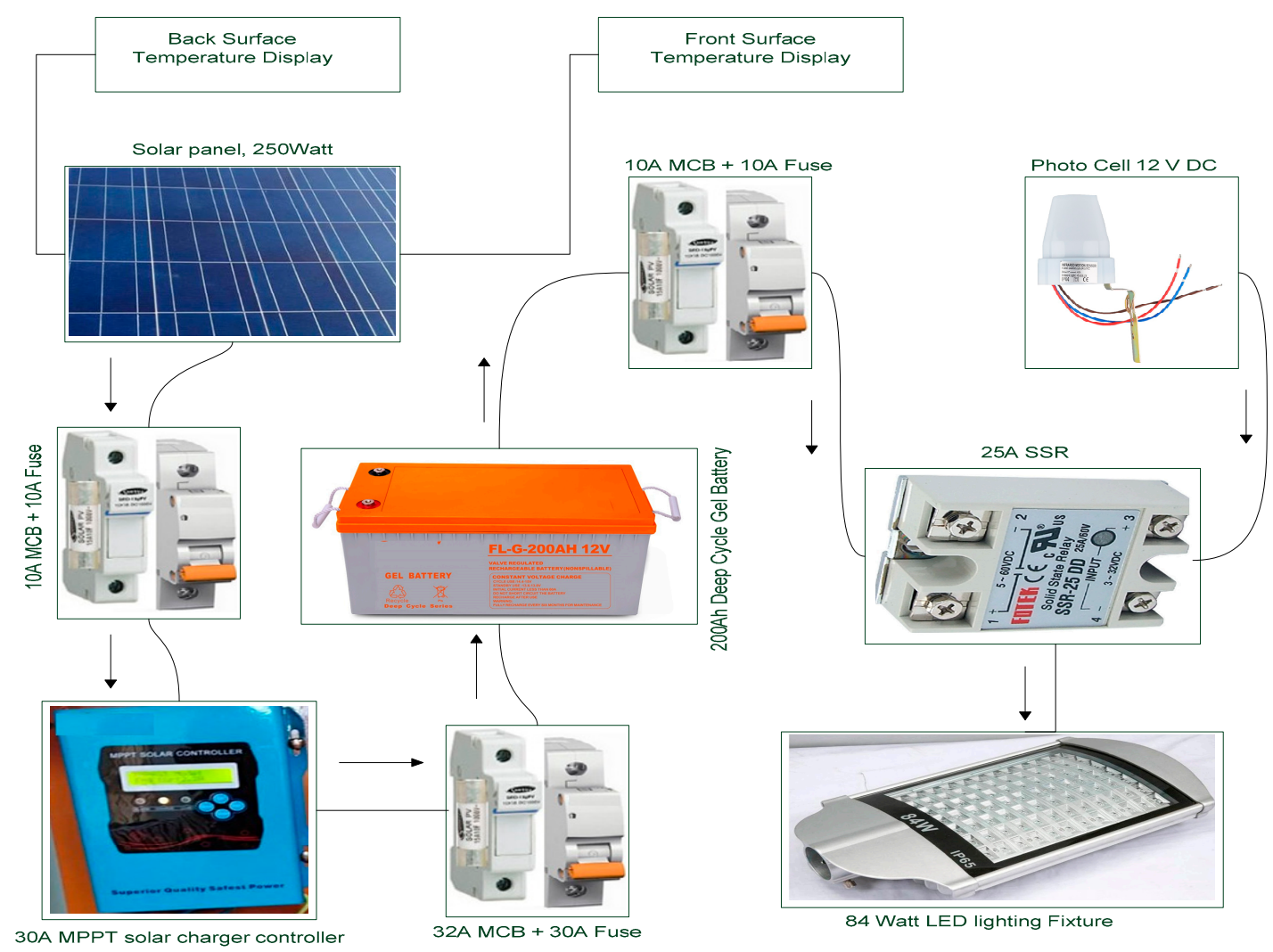

Figure 15. Schematic diagram of the experimental model implementation.

\subsection{The Experimental Setup Model without Heat Sink}

This case elaborates the effect of temperature on the solar panel performance without using the heat sink as detailed in Figure 3. The average readings during daylight hours in June are presented in Table 14 , where $T_{a}$ is the average ambient temperature, $T_{S F S}$ is the solar panel front surface temperature, and $T_{S B S}$ is the temperature of the solar panel back surface.

Table 14. Readings without a heat sink.

\begin{tabular}{llllllll}
\hline Time $(\mathrm{h})$ & $\boldsymbol{T}_{\boldsymbol{a}}\left({ }^{\circ} \mathbf{C}\right)$ & $\boldsymbol{T}_{\boldsymbol{S F S}}\left({ }^{\circ} \mathrm{C}\right)$ & $\boldsymbol{T}_{S B S}\left({ }^{\circ} \mathbf{C}\right)$ & $\boldsymbol{V}_{\boldsymbol{o c}}(\mathrm{V})$ & $\boldsymbol{V}_{\boldsymbol{m p p}}(\mathrm{V})$ & $\boldsymbol{I}_{\boldsymbol{m p p}}(\mathrm{A})$ & $\boldsymbol{P}_{\boldsymbol{m p p}}(\mathrm{W})$ \\
\hline 05:30 a.m. & 28 & 28 & 28 & 21.1 & 21.1 & 0.05 & 1 \\
06:00 a.m. & 28.5 & 29 & 28.8 & 28.2 & 17.7 & 0.4 & 7 \\
06:30 a.m. & 28.5 & 29.6 & 29.4 & 29.9 & 17.9 & 0.5 & 8 \\
07:00 a.m. & 29 & 31 & 30.3 & 31.3 & 21.2 & 0.7 & 14 \\
07:30 a.m. & 30.5 & 33.4 & 32.6 & 32.3 & 24.5 & 1.1 & 25 \\
08:00 a.m. & 32.5 & 33.5 & 33 & 32.8 & 23.6 & 1.8 & 40 \\
08:30 a.m. & 34.5 & 38 & 37 & 33 & 23 & 2.3 & 50 \\
09:00 a.m. & 37 & 41.2 & 39.6 & 32.8 & 21.6 & 3.2 & 64 \\
09:30 a.m. & 38 & 43.5 & 42 & 31.7 & 21 & 3.6 & 73 \\
\hline
\end{tabular}


Table 14. Cont.

\begin{tabular}{llllllll}
\hline Time (h) & $\boldsymbol{T}_{\boldsymbol{a}}\left({ }^{\circ} \mathbf{C}\right)$ & $\boldsymbol{T}_{S F S}\left({ }^{\circ} \mathbf{C}\right)$ & $\boldsymbol{T}_{S B S}\left({ }^{\circ} \mathbf{C}\right)$ & $V_{\boldsymbol{o c}}(\mathbf{V})$ & $V_{\text {mpp }}(\mathbf{V})$ & $\boldsymbol{I}_{\boldsymbol{m p p}}(\mathrm{A})$ & $\boldsymbol{P}_{\boldsymbol{m p p}}(\mathbf{W})$ \\
\hline 10:00 a.m. & 38.5 & 44 & 42.5 & 30.6 & 20.9 & 3.9 & 78 \\
10:30 a.m. & 39 & 46.1 & 44.6 & 30.4 & 20.3 & 4.4 & 86 \\
11:00 a.m. & 39.5 & 48 & 46 & 30.2 & 20 & 4.9 & 96 \\
11:30 a.m. & 40 & 49.3 & 47 & 30 & 18.7 & 5.4 & 99 \\
12:00 p.m. & 41 & 49.5 & 47.2 & 29.8 & 18.3 & 5.6 & 100 \\
12:30 p.m. & 41.3 & 49.6 & 47.3 & 29.6 & 18 & 5.8 & 103 \\
01:00 p.m. & 41.6 & 49.7 & 47.5 & 29.4 & 17.6 & 6 & 101 \\
01:30 p.m. & 41.8 & 50.1 & 48 & 29 & 17.5 & 5.9 & 98 \\
02:00 p.m. & 42.4 & 50.9 & 48.7 & 28.4 & 17.4 & 5.8 & 94 \\
02:30 p.m. & 42 & 50.2 & 48.5 & 28.6 & 17.1 & 5.7 & 93 \\
03:00 p.m. & 40.2 & 49 & 47 & 29.6 & 18.8 & 5 & 89 \\
03:30 p.m. & 40.5 & 48 & 46.5 & 30.2 & 20.1 & 4.2 & 80 \\
04:00 p.m. & 39.5 & 46.5 & 45.2 & 31 & 21.6 & 3.4 & 70 \\
04:30 p.m. & 39 & 45 & 43.6 & 31.4 & 22.4 & 2.7 & 56 \\
05:00 p.m. & 38.5 & 43 & 41.5 & 31.8 & 22.8 & 1.8 & 37 \\
05:30 p.m. & 38 & 42 & 41 & 32 & 18.6 & 1.4 & 20 \\
06:00 p.m. & 37 & 40.5 & 36.5 & 28.5 & 17.8 & 0.34 & 5 \\
06:30 p.m. & 35.2 & 38 & 35.5 & 26.4 & 0 & 0 & 0 \\
07:00 p.m. & 31 & 32 & 30.5 & 24 & 0 & 0 & 0 \\
07:30 p.m. & 28 & 30 & 30 & 1.5 & 0 & 0 & 0 \\
08:00 p.m. & 28 & 28.5 & 28.5 & 1.5 & 0 & 0 & 0 \\
\hline
\end{tabular}

\subsection{The Experimental Setup Model with an Aluminum Heat Sink}

This case studied the effect of temperature on the solar panel performance using the aluminum heat sink as detailed in Figure 7. The average readings during daylight hours in June are presented in Table 15, where $T_{H S S}$ is the heat sink outlet surface temperature.

Table 15. Experimental readings with an aluminum heat sink.

\begin{tabular}{llllllll}
\hline Time (hr.) & $\boldsymbol{T}_{\boldsymbol{a}}\left({ }^{\circ} \mathbf{C}\right)$ & $\boldsymbol{T}_{\boldsymbol{S F S}}\left({ }^{\circ} \mathbf{C}\right)$ & $\boldsymbol{T}_{\boldsymbol{H S S}}\left({ }^{\circ} \mathbf{C}\right)$ & $\boldsymbol{V}_{\boldsymbol{o c}}(\mathbf{V})$ & $\boldsymbol{V}_{\boldsymbol{m p p}}(\mathbf{V})$ & $\boldsymbol{I}_{\boldsymbol{m p p}}(\mathbf{A})$ & $\boldsymbol{P}_{\boldsymbol{m p p}}(\mathbf{W})$ \\
\hline 05:30 a.m. & 28 & 28 & 28 & 21.1 & 21.1 & 0.04 & 1 \\
06:00 a.m. & 28.5 & 29 & 28.5 & 28.2 & 17.3 & 0.36 & 7 \\
06:30 a.m. & 28.5 & 29.6 & 29.4 & 29.9 & 17.9 & 0.4 & 8 \\
07:00 a.m. & 29 & 30.8 & 29.8 & 31.3 & 21.2 & 0.72 & 18 \\
07:30 a.m. & 30.5 & 33 & 31 & 32.3 & 26.7 & 1.24 & 32 \\
08:00 a.m. & 32.5 & 33.5 & 32.7 & 33.8 & 26.7 & 1.85 & 48 \\
08:30 a.m. & 34.5 & 37 & 35 & 34.5 & 26.5 & 2.45 & 60 \\
09:00 a.m. & 37 & 40 & 38 & 34.2 & 26 & 3.1 & 78 \\
09:30 a.m. & 38 & 42.5 & 39 & 33.8 & 25.6 & 3.4 & 85 \\
10:00 a.m. & 38.5 & 43 & 39.5 & 33.7 & 25.2 & 3.7 & 90 \\
10:30 a.m. & 39 & 44.1 & 39.8 & 33.4 & 25 & 4 & 96 \\
11:00 a.m. & 39.5 & 47 & 40.2 & 33.2 & 24 & 4.4 & 102 \\
11:30 a.m. & 40 & 47.3 & 40.8 & 33 & 22 & 5 & 104 \\
12:00 p.m. & 41 & 47.5 & 41.5 & 32.8 & 21.8 & 5.1 & 105 \\
12:30 p.m. & 41.3 & 47.6 & 41.8 & 32.6 & 21.4 & 5.2 & 107 \\
01:00 p.m. & 41.6 & 47.6 & 42 & 32.4 & 20.4 & 5.5 & 108 \\
01:30 p.m. & 41.8 & 48 & 42.2 & 31 & 20 & 5.6 & 103 \\
02:00 p.m. & 42.4 & 48.2 & 42.6 & 30.8 & 20 & 5.5 & 102 \\
02:30 p.m. & 42 & 47.8 & 42.4 & 30.6 & 19.8 & 5.5 & 99 \\
03:00 p.m. & 40.2 & 47 & 40.5 & 30.4 & 19.4 & 5 & 92 \\
03:30 p.m. & 40.5 & 45.5 & 40.2 & 30.2 & 22.8 & 4 & 86 \\
04:00 p.m. & 39.5 & 44 & 40 & 32.5 & 22.4 & 3.8 & 80 \\
04:30 p.m. & 39 & 43 & 40 & 32.8 & 22.2 & 3.4 & 70 \\
05:00 p.m. & 38.5 & 42.6 & 39.6 & 33.8 & 22 & 2.72 & 56 \\
05:30 p.m. & 38 & 42 & 38.5 & 34 & 18.8 & 1.92 & 32 \\
06:00 p.m. & 37 & 40.5 & 37.8 & 29.5 & 18.5 & 1.2 & 20 \\
06:30 p.m. & 35.2 & 38 & 35.5 & 28.5 & 17.8 & 0.52 & 8 \\
07:00 p.m. & 31 & 35 & 31 & 26 & 0 & 0 & 0 \\
07:30 p.m. & 28 & 30 & 28 & 1.5 & 0 & 0 & 0 \\
08:00 p.m. & 28 & 28 & 28 & 1.5 & 0 & 0 & 0 \\
\hline & & & & & & &
\end{tabular}




\subsection{Comparison and Comments}

This section discusses the comparison of the results of the two experimental setup models, with and without the aluminum heat sink. The comparison at this stage is limited to the solar panel electrical characteristics at variable ambient temperatures during different parts of the day, as shown in Figure 16. The maximum solar panel front surface temperature without cooling is $50.8^{\circ} \mathrm{C}$ and it dropped to $48.2{ }^{\circ} \mathrm{C}$ for the same time of the day (2:00 p.m.) when the aluminum heat sink was used- a drop of about $3.7 \%$. When the maximum solar panel back surface temperature without cooling was $48.5^{\circ} \mathrm{C}$, it dropped to $42.4{ }^{\circ} \mathrm{C}$ for the same time (2:30 p.m.) when the heat sink was used- a decrease of $14.3 \%$. Results of the experiment for the solar panel output voltage, current, and power are plotted with ambient temperature as shown in Figures 17-19, respectively. The maximum open circuit voltage $V_{o c}(V)$ without heat sink is recorded as $33 \mathrm{~V}$ at 8:30 a.m. while this value is $34.5 \mathrm{~V}$ (at 8:30 a.m.) when the heat sink is used-an increase of about $4.5 \%$. Moreover, maximum power point voltage $V_{m p p}$ is changed from 24.5 to $26.7 \mathrm{~V}$ at 7:30 a.m. when a heat sink is used-an increase of $9 \%$. The maximum power point current $I_{m p p}$ is recorded as 6 A without heat sink while it was 6.5 A when heat sink was used, time being constant at 1:00 p.m.- -a decrease of $6.67 \%$. From the results of this experiment, it can be concluded that the electrical characteristics of the solar panel are enhanced when aluminum heat sink is used. This is because of a decrease in the solar cell temperature leading to a rise in the open circuit voltage as well as the maximum power voltage. There is a slight decrease in output current due to the fall in temperature as shown in Figures 17 and 18, respectively. The output power is increased and the electrical energy generated by the solar panel is increased as shown in Figure 19. Values for all points are increased-for example at 9 a.m. the power increased from 63 to 79 which is a $25.4 \%$ increase at an ambient temperature of $37^{\circ} \mathrm{C}$. As a result of the increase in solar panel output power throughout the daylight hours, the output energy increased from 1587 watt/day to 1797 watt/day amounting to a $13.23 \%$ increase overall. The insertion of aluminum heat sink to the solar panel decreases the solar cell temperature and limits the hot spot phenomena, which increases the life of the unit. Figure 20 shows the thermal images of solar panel surfaces with and without aluminum heat sink.

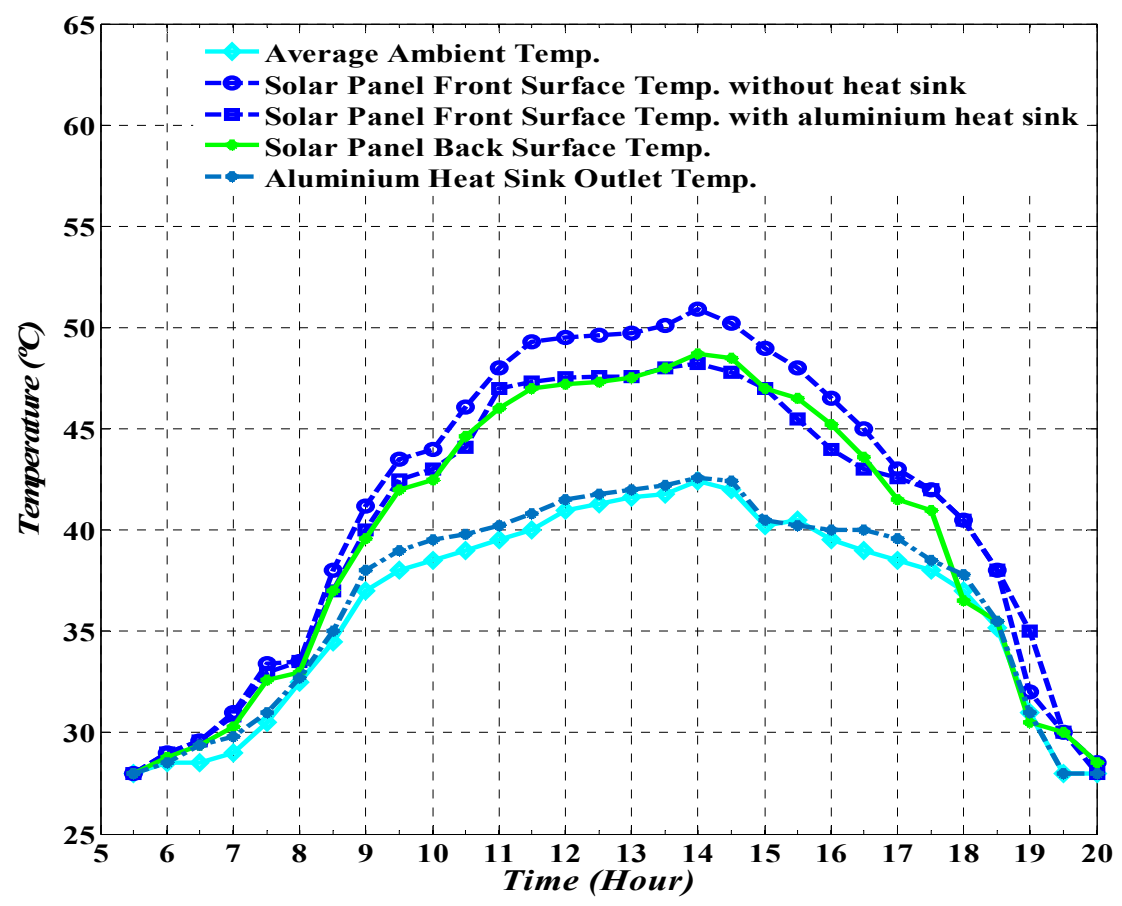

Figure 16. Temperatures curves of the solar panel experimental model. 


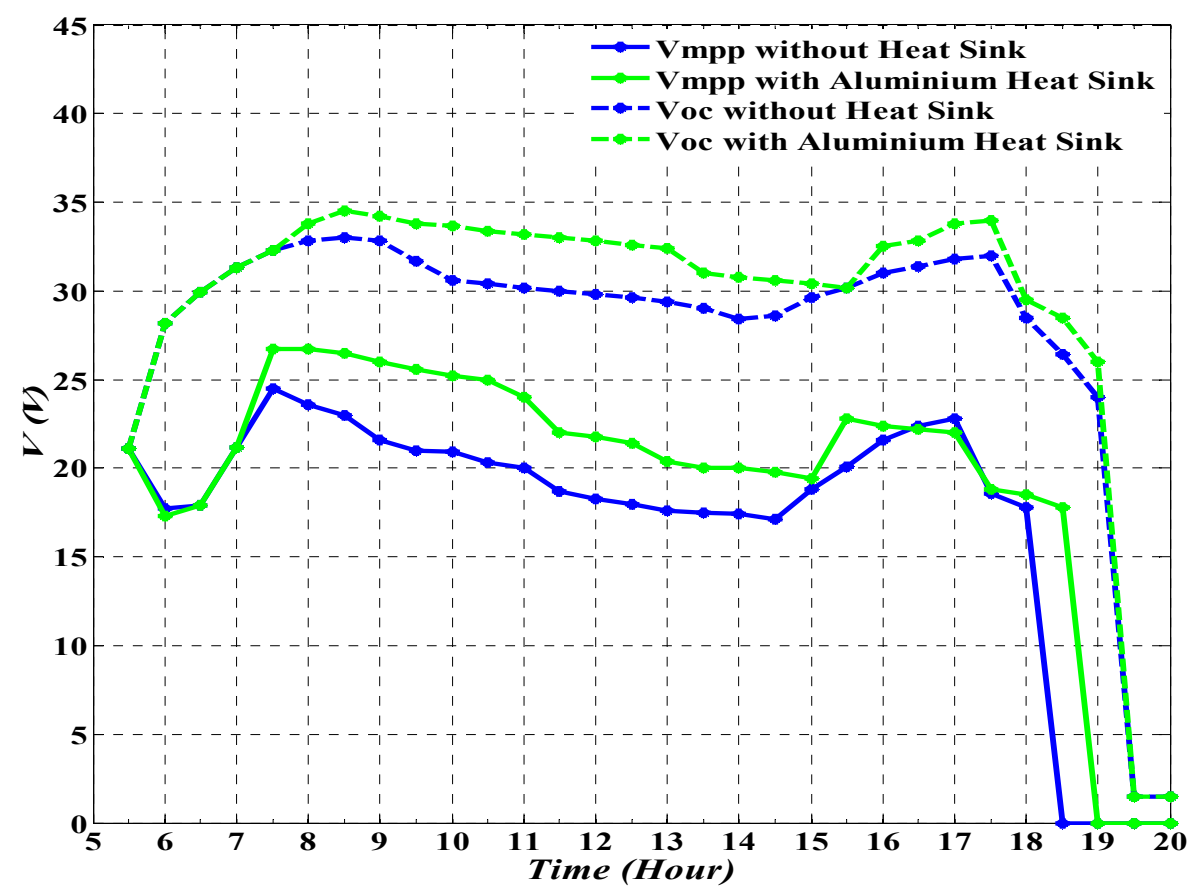

Figure 17. Output voltage curves of the solar panel experimental model.

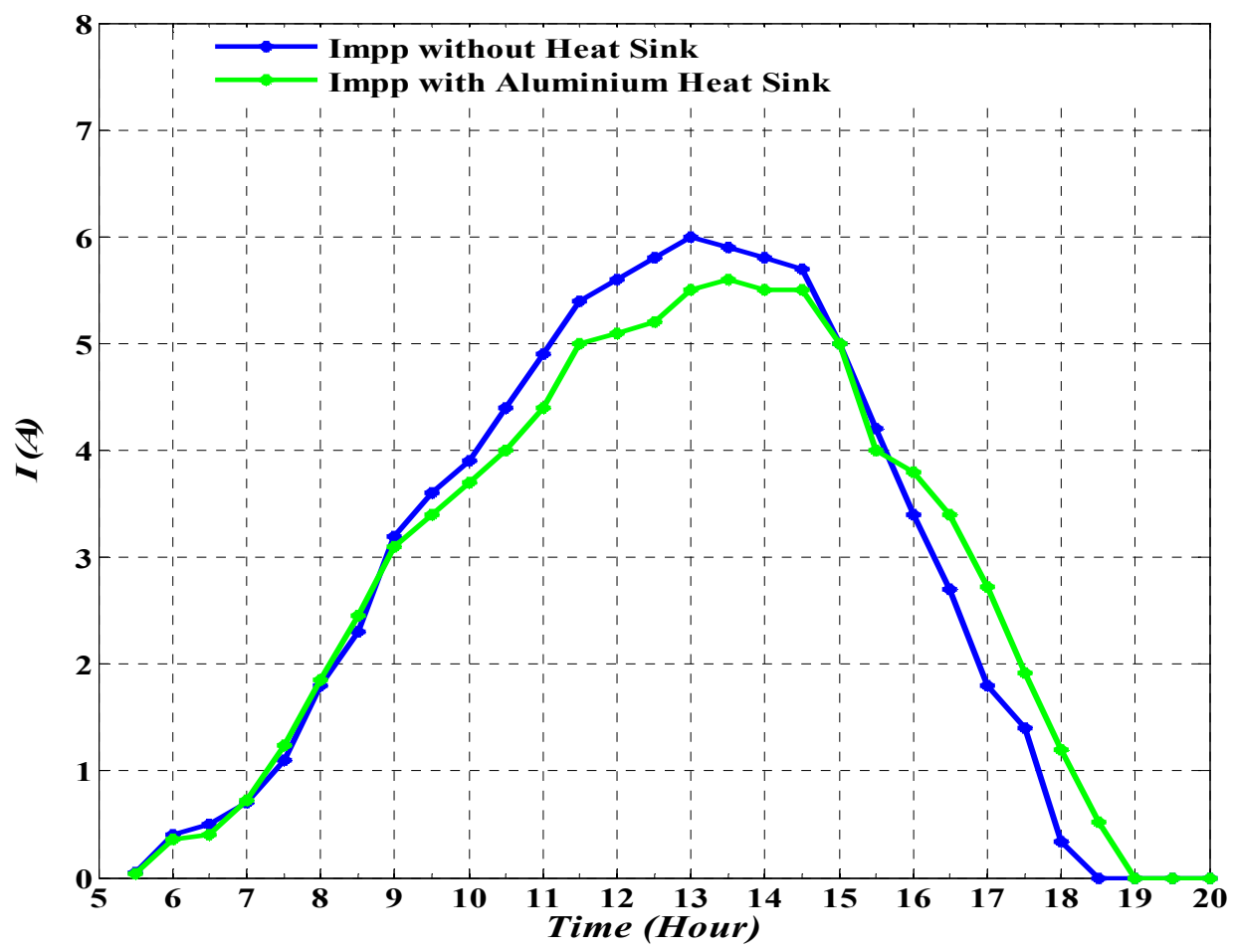

Figure 18. Output current curves of the solar panel experimental model. 


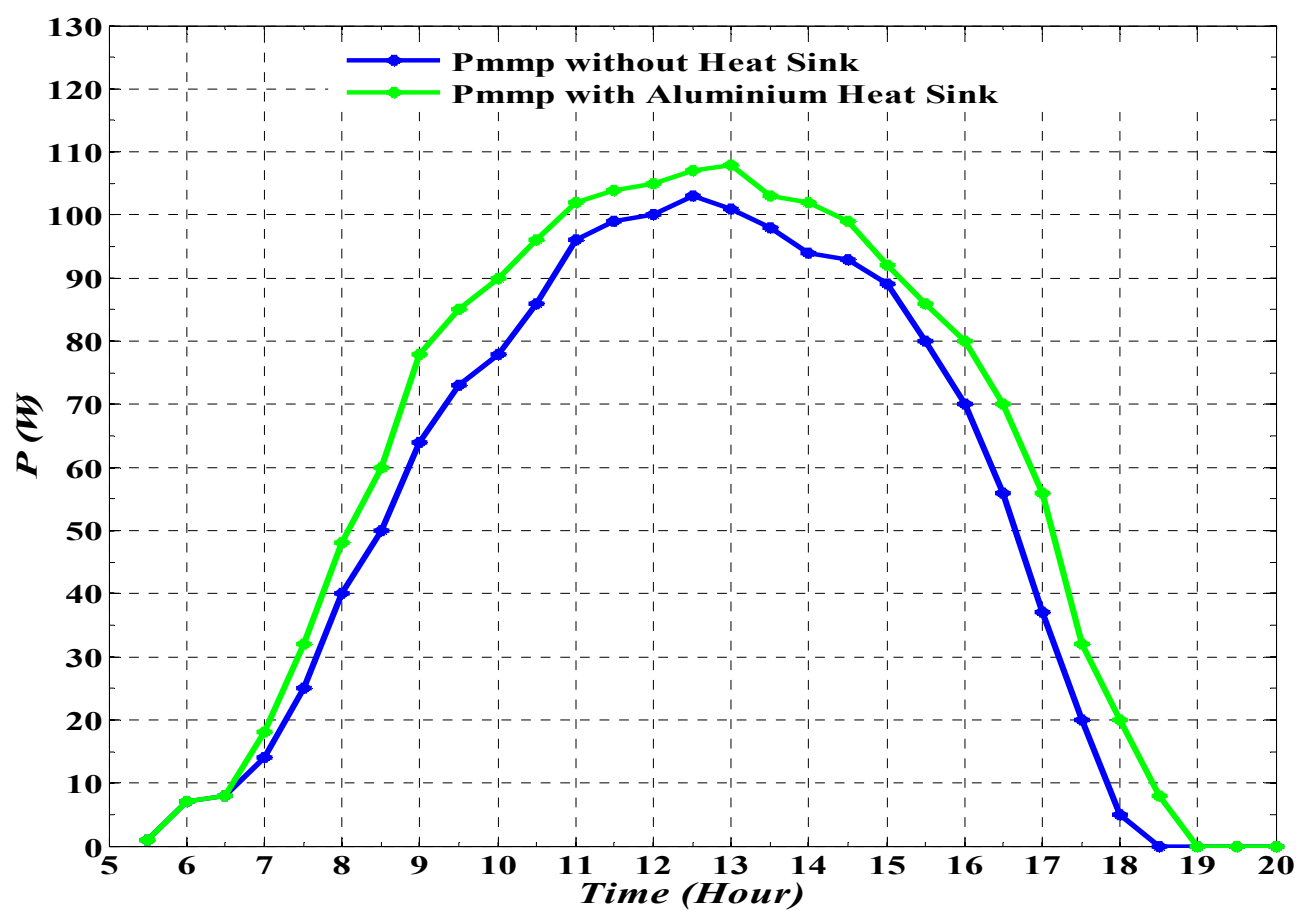

Figure 19. The output power curves of solar panel experimental model.
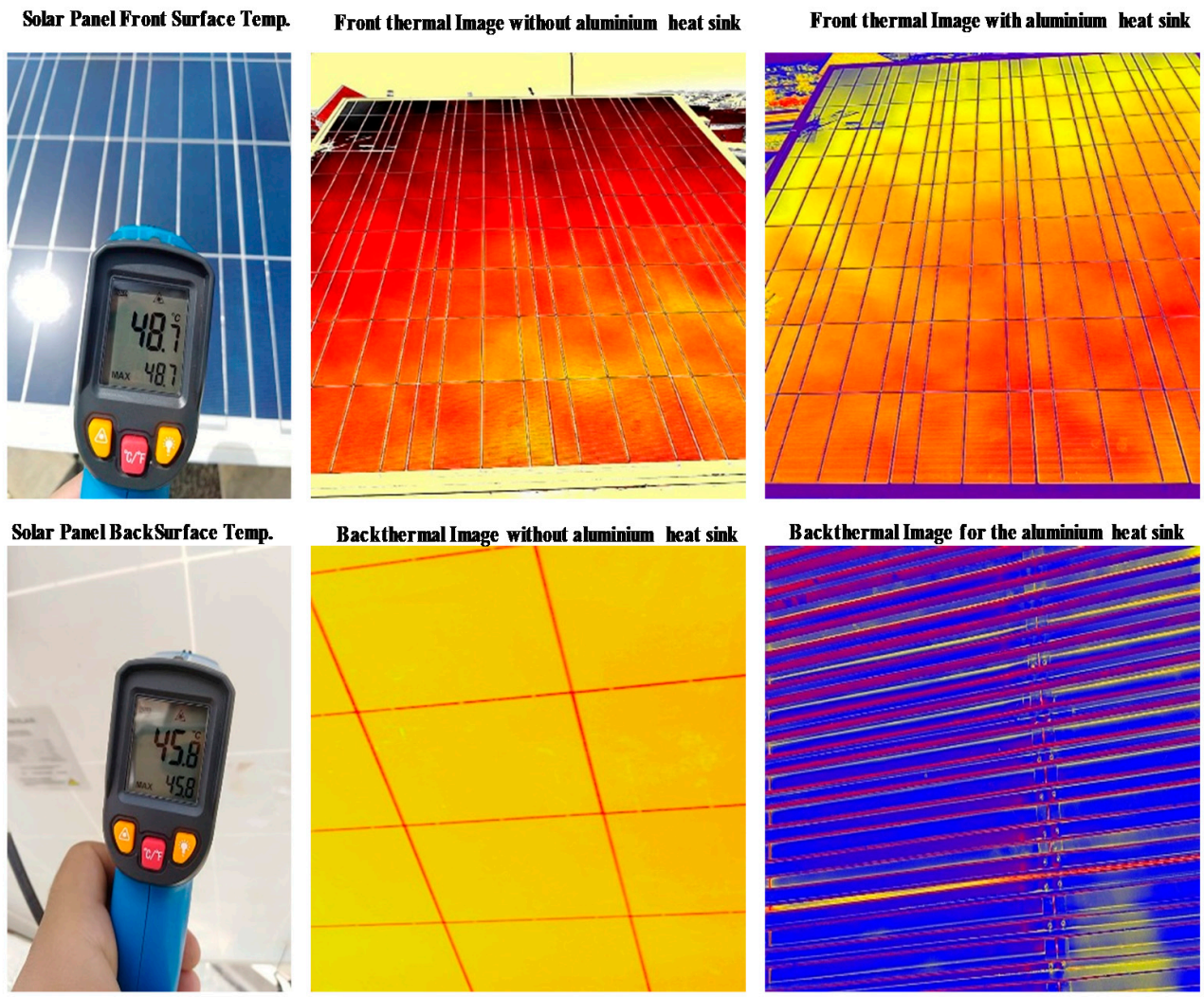

Figure 20. Thermal images of the solar panel surfaces without and with the aluminum heat sink. 


\section{Conclusions}

This paper discussed steady state heat transfer through solar panel layers and studied the effect of high temperatures on the solar panel performance in a hot desert environment with varying wind speed. In our simulation it has been found that the solar cell temperature is decreased when an aluminum heat sink is installed. The total thermal resistance is decreased due to the high thermal conductivity and large surface area of the aluminum heat sink due to its fins. Subsequently, there is acceleration of heat transfer through the solar panel back surface leading to a decrease of $11^{\circ} \mathrm{C}$ in the solar cell temperature. In the experimental stage, it was concluded that the installation of aluminum heat sink on the solar panel back surface leads to a decrease in the solar cell temperature by $16.4 \%$, which leads to an enhancement of the electrical characteristics in the form of increase in both the open circuit voltage and maximum power point voltage. It also produces a slight reduction in the maximum power point current. In the experimental stage, the overall extracted electrical energy from the solar panel with aluminum heat sink is increased by more than $13.23 \%$ per day when compared with the case when no such a heat sink was not used. This validates the theoretical and simulation studies that have shown that the heat sink installation effectively mitigates the temperature negative effect and enhances the solar panel electrical performance.

Therefore, this paper concludes that the installation of the aluminum heat sink on the back surface of solar panels leads to a mitigation of the solar cell temperature and limits the hot spot phenomena. It also enhances the electrical characteristics and increases both solar panel efficiency and lifetime.

Author Contributions: Y.H. did the experimental work and reported the results, shared the analysis and writing of the manuscript. M.A.I. guided the proposed electrical design, in addition to the editing and review of the written manuscript, O.M.A.-R. and B.A.H. strategy proposed and guided the mechanical design of the heat think. and contribute to the manuscript writing. M.O., A.A. and A.E.A. was responsible for the guidance and a number of key suggestions in addition to the editing and review of the written manuscript. All authors have read and agreed to the published version of the manuscript.

Funding: This research was co-funded by the Renewable Energy \& Smart Grid Lab (RESGL), Electrical Engineering and Computer Department, KAU by providing facilities and support. Y. Hassan and M. Orabi would also like to express our gratitude for Aswan Power Electronic Applications Research Center (APEARC), Aswan University for their immense support under STDF grant ID: 15261. Abdelali El Aroudi would like to thank the Spanish Agencia Estatal de Investigación (AEI) and the Fondo Europeo de Desarrollo Regional (FEDER) under grant DPI2017-84572-C2-1-R (AEI/FEDER, UE).

Acknowledgments: The authors would like to thank. Gulf Lighting Company helped us the manufacture of the aluminum heat sink which we used in our experiments, for which we are thankful to them.

Conflicts of Interest: The authors declare no conflict of interest.

\section{Nomenclature}

$Q_{C} \quad \begin{aligned} & \text { Amount of energy inherited through the glass } \\ & \text { surface (Joule or W.h). }\end{aligned}$
$Q_{e l} \quad \begin{aligned} & \text { Useful energy is converted to electrical energy } \\ & \text { (Joule or W.h). }\end{aligned}$
$Q_{t h} \quad \begin{aligned} & \text { Thermal energy losses (Joule or W.h). } \\ & Q_{f T}\end{aligned} \quad \begin{aligned} & \text { Total heat transfer rate from the heat sink } \\ & \text { surface (Joule or W.h). }\end{aligned}$
$Q_{\text {fins }} \quad \begin{aligned} & \text { Heat transfer rate from the heat sink fins } \\ & \text { surface (Joule or W.h). }\end{aligned}$
$Q_{u n f i n s} \quad \begin{aligned} & \text { Heat transfer rate from the heat sink unfins } \\ & \text { surface (Joule or W.h). }\end{aligned}$
$Q_{r} \quad \begin{aligned} & \text { Thermal energy rating that results from the air } \\ & \text { touching surfaces (Joule or W.h). }\end{aligned}$
$\alpha_{C} \quad \begin{array}{l}\text { Cell absorptivity. } \\ \lambda\end{array} \quad \begin{array}{l}\left.\text { Thermal diffusivity (= } 2.84 \times 10^{-5} \mathrm{~m}^{2} / \mathrm{s}\right) . \\ \tau_{g}\end{array} \quad \begin{array}{l}\text { Glass transmissivity. } \\ q\end{array} \quad$ Electron charge (=1.602 $\left.\times 10^{-19} \mathrm{C}\right)$.
$R_{c} \quad$ Contact thermal resistance $\left({ }^{\circ} \mathrm{C} / \mathrm{W}\right)$.
$R_{H s} \quad$ Lumped heat sink thermal resistance $\left({ }^{\circ} \mathrm{C} / \mathrm{W}\right)$.
$R_{\text {fin }}$ Fins thermal resistance $\left({ }^{\circ} \mathrm{C} / \mathrm{W}\right)$.
$R_{\text {fins }}$ Lumped thermal resistance of total number
Rins of fins $\left({ }^{\circ} \mathrm{C} / \mathrm{W}\right)$.
$R_{f a} \quad$ Thermal resistance of the ambient air through the
film $\left({ }^{\circ} \mathrm{C} / \mathrm{W}\right)$.
$R_{b p b}$ Thermal resistance of the back heat sink base
$R_{i n r} \quad$ Interface thermal denoted $\left({ }^{\circ} \mathrm{C} / \mathrm{W}\right)$.
$R_{s p} \quad$ Heat sink spread thermal resistance $\left({ }^{\circ} \mathrm{C} / \mathrm{W}\right)$.
$R_{c d} \quad$ Conduction thermal network resistance $\left({ }^{\circ} \mathrm{C} / \mathrm{W}\right)$.
$R_{c v} \quad$ Convection thermal network resistances $\left({ }^{\circ} \mathrm{C} / \mathrm{W}\right)$.
$R_{r} \quad$ Radiation thermal network resistance $\left({ }^{\circ} \mathrm{C} / \mathrm{W}\right)$. 
$\psi_{a v} \quad$ Dimensionless spreading resistance

$S_{r} \quad$ Solar radiation $\left(\mathrm{W} / \mathrm{m}^{2}\right)$.

$f_{p} \quad$ Packing factor that refers to the area filled

$f_{p} \quad$ with solar cells from the total surface area.

FF Fill factor.

$g \quad$ Gravitational constant $\left(=9.81 \mathrm{~m} / \mathrm{s}^{2}\right)$.

A Surface area $\left(\mathrm{m}^{2}\right)$.

$A_{e} \quad$ Edge area $\left(\mathrm{m}^{2}\right)$.

$A_{f} \quad$ Fin cross-sectional area $\left(\mathrm{m}^{2}\right)$.

$A_{f o} \quad$ Vehicle front area $\left(\mathrm{m}^{2}\right)$.

$A_{\text {fins }} \quad$ Fins area of the heat $\operatorname{sink}\left(\mathrm{m}^{2}\right)$.

$A_{\text {unfins }}$ Total unfins area of the heat sink $\left(\mathrm{m}^{2}\right)$.

$H \quad$ Heat sink height (m).

$W \quad$ Heat sink width (m).

$d_{f} \quad$ Spacing between two consequential fins (m).

$\eta_{e l} \quad$ Eelectrical efficiency.

$\eta_{0} \quad$ Nominal electrical efficiency

$\eta_{\text {th }} \quad$ Thermal efficiency.

$\eta_{\text {fins }} \quad$ Efficiency of heat sink fins.

$\beta$ Temperature coefficient that relies on the material type $\left(\mathrm{K}^{-1}\right)$.

$T_{0} \quad$ Solar cell temperature at the () Standard Test Conditions $\left({ }^{\circ} \mathrm{C}\right.$ or $\left.\mathrm{K}\right)$.

$T_{a} \quad$ Average ambient temperature $\left({ }^{\circ} \mathrm{C}\right.$ or $\left.\mathrm{K}\right)$.

$T_{C} \quad$ Solar cell temperature at the operating

conditions $\left({ }^{\circ} \mathrm{C}\right.$ or $\left.\mathrm{K}\right)$.

$T_{G} \quad$ Glass temperature $\left({ }^{\circ} \mathrm{C}\right.$ or $\left.\mathrm{K}\right)$.

$T_{b} \quad$ Back sheet temperature $\left({ }^{\circ} \mathrm{C}\right.$ or $\left.\mathrm{K}\right)$.

$T_{C}{ }^{*} \quad$ Cell temperature when the efficiency

Approaching to zero $\left({ }^{\circ} \mathrm{C}\right.$ or $\left.\mathrm{K}\right)$.

$T_{S} \quad$ Sky temperature $\left({ }^{\circ} \mathrm{C}\right.$ or $\left.\mathrm{K}\right)$.

$T_{H s} \quad$ Temperature of heat sink surface $\left({ }^{\circ} \mathrm{C}\right.$ or $\left.\mathrm{K}\right)$.

$T_{m} \quad$ Mean absorbed cell temperature $\left({ }^{\circ} \mathrm{C}\right.$ or $\left.\mathrm{K}\right)$.

$\delta \quad$ Volumetric coefficient of expansion $\left(\mathrm{K}^{-1}\right)$

$a \quad$ Diode ideality factor $(1 \leq a \leq 2)$.

$\rho \quad$ Density of the air $\left(=1.225 \mathrm{~kg} / \mathrm{m}^{3}\right)$.

$P_{\text {mpp }} \quad$ Output power (W) that is tracked at the

$P_{\text {mpp }} \quad$ Maximum Power Point (MPP).

$V_{m p p} \quad$ Voltage of the $P V$ source at the MPP (V).

$V_{O C} \quad$ Voltage of the $P V$ source at open circuit $(\mathrm{V})$.

$V_{p v} \quad$ PV output voltage $(\mathrm{V})$.

$V_{T} \quad$ Thermal voltage $(\mathrm{V})$.

$V_{d} \quad$ Diode voltage $(\mathrm{V})$.

$I_{m p p} \quad$ Current of the $P V$ source at the MPP (A).

$I_{S C} \quad$ Current of the $P V$ source at short circuit (A).

$I_{p v} \quad$ PV output current (A).

$I_{d} \quad$ Diode current (A).

$I_{L} \quad$ Light current (A).

$I_{0} \quad$ Reverse saturation current (A).

$m_{A} \quad$ Air mass flow rate.

$\zeta \quad$ Reflection coefficient of the glass $=0.1$.
$R_{S} \quad$ Series resistance of single diode solar cell $(\Omega)$.

$R_{s h} \quad$ Shunt resistance of single diode solar cell $(\Omega)$.

$k_{e} \quad$ Thermal conductivity of the edge insulation $[\mathrm{W} /(\mathrm{m} \cdot \mathrm{K})]$.

$k \quad$ Thermal conductivity $[\mathrm{W} /(\mathrm{m} . \mathrm{K})]$.

$k_{a} \quad$ Thermal conductivity of the air $(=0.0291[\mathrm{~W} /(\mathrm{m} . \mathrm{K})])$.

$K_{r} \quad$ Interface thermal conductivity [W/(m.K)].

$K_{B Z} \quad$ Boltzmann constant $\left(=1.3807 \times 10^{-23} \mathrm{~J} / \mathrm{K}\right)$.

$U_{L} \quad$ Overall heat transfer coefficient.

$U_{t} \quad$ Heat transfer coefficients of top.

$U_{b} \quad$ Heat transfer coefficients of the bottom.

$U_{e} \quad$ Heat transfer coefficients of the edges.

$t \quad$ Thickness of any solar panel layer $(\mathrm{mm})$.

$t_{b p} \quad$ Thickness of heat sink base plate $(\mathrm{mm})$.

$t_{f} \quad$ Thickness of heat sink fin (mm).

$t_{e} \quad$ Edge insulation thickness (mm).

$h_{r} \quad$ Everall heat transfer coefficient.

$h_{r} \quad$ Radiation heat transfer coefficient.

$h_{c v} \quad$ Convection heat transfer coefficient.

$h_{c} \quad$ Surrounding air heat transfer coefficient due to convection

Convective heat transfer coefficient due to wind speed.

$C_{A} \quad$ Air specific heat

$C_{D} \quad$ Coefficient of aerodynamic drag which depends on vehicle brand and is in the range of 0.297.

$C_{g} \quad$ Constant $=2.677 \times 10^{4}$ for silicon.

$c_{e} \quad$ Empirical constant in the range of 0.593.

Bandgap energy that relies on the material type, $E_{\text {go }}=1.12 \mathrm{eV}$ or $1.794 \times 10^{-19} \mathrm{~J}$.

$\varepsilon_{r} \quad$ Material emissivity of heat sink.

$\varepsilon \quad$ Emissivity coefficient of any solar panel layer.

$\mu \quad$ Kinematic viscosity of the air $\left(=1.96 \times 10^{-5} \mathrm{~m}^{2} / \mathrm{s}\right)$. Porosity hole area to solar panel area $\left(=5.67 \times 10^{-8} \mathrm{~J} / \mathrm{K}\right)$

$p \quad$ Perimeter of solar panel (m).

$p_{f} \quad$ Fin perimeter $(\mathrm{m})$.

Resultant wind speed due to natural air and turbulence air $(\mathrm{m} / \mathrm{s})$.

$\omega_{s} \quad$ Wind speed of natural air $(\mathrm{m} / \mathrm{s})$.

$\omega_{t} \quad$ Wind speed of turbulence air $(\mathrm{m} / \mathrm{s})$.

$\omega_{v} \quad$ Vehicle average speed $(\mathrm{m} / \mathrm{s})$.

$L_{v} \quad$ The scaled turbulence motion length (m).

$L_{c h} \quad$ Surface characteristic length of solar panel (m).

$n_{v} \quad$ Vehicles number per unit length.

$N_{f} \quad$ Total number of fins.

$\mathrm{Nu} \quad$ Nusselt number.

Re Reynold number.

$\mathrm{Pr} \quad$ Prandtl number.

$\mathrm{Ra}$ Rayleigh number.

$G_{r} \quad$ Grashoff number. 


\section{Appendix A}

The mathematical model of a single diode solar cell electrical model is described (as shown in Figure 5) for a solar panel that consists of $n_{c}$ solar cells. The open circuit voltage is denoted by $V_{o c}$. The short circuit current is $I_{s c}$, while $V_{p v}$, and $I_{p v}$ are the output voltage and current. $I_{L}$ is the light current, $I_{o}$ is the reverse saturation current, while $V_{d}$ and $I_{d}$ are the diode voltage and current respectively. All these parameters rely on the thermal voltage $V_{T}$ that depends on the solar cell temperature [24,30,31,47-49], where $(1 \leq a \leq 2)$ is the diode ideality factor, $\left(K_{B Z}=1.3807 \times 10^{-23} \mathrm{~J} / \mathrm{K}\right)$ is the Boltzmann constant, $\left(q=1.602 \times 10^{-19} \mathrm{C}\right)$ is the electron charge. The electrical performance is described as per the following equations:

$$
\begin{gathered}
V_{T}=\frac{a K_{B Z} T_{C}}{q} \\
V_{o c}=V_{T} \ln \left(\frac{I_{s c}}{I_{o}}+1\right) \\
I_{s c}=I_{L}-I_{o}\left(e^{\frac{I s c R_{s}}{V_{T}}}-1\right)-\frac{I_{s c} R_{s}}{R_{s h}} \\
I_{L}=I_{s c} e^{\frac{V_{o c}}{V_{T}}\left(e^{\frac{V_{o c}}{V_{T}}}-1\right)-\frac{V_{o c}}{R_{s h}}} \\
I_{o}=I_{s c} e^{\left(\frac{V_{o c}}{V_{T}}+\frac{E_{g o}}{K_{B Z} T_{o}}-\frac{E_{g}}{K_{B Z} T_{C}}\right)} \\
\frac{E_{g}}{E_{g o}}=1-C_{g}\left(T_{C}-T_{o}\right) \\
V_{d}=V_{T} \ln \left(\frac{I_{d}}{I_{o}}+1\right) \\
I_{d}=I_{o}\left(e^{\frac{V_{d}}{V_{T}}}-1\right) \\
I_{p v}=I_{s c}-I_{o}\left(e^{\frac{\left(V_{p v}+I_{p v} R_{s}\right)}{V_{T}}}-1\right)-\frac{V_{p v}+I_{p v} R_{s}}{R_{s h}}
\end{gathered}
$$

where $E_{g}$ is the bandgap energy that relies on the material type, $E_{g o}=1.12 \mathrm{eV}$ or $1.794 \times 10^{-19} \mathrm{~J}$ and the constant $C_{\mathrm{g}}=2.677 \times 10^{4}$ for silicon. The output power $P_{m p p}$ at the MPP is given in Equation (6). There are many methods to calculate the Voltage $V_{m p p}$ and current $I_{m p p}$ at the MPP, as mentioned in [31], by differentiation of the output power $P=V I$ with respect to the voltage $V$ that is given in Equation (A11). The current $I_{m p p}$ at the MPP is given by Equation (A12), then $V_{m p p}$ and $I_{m p p}$ are given by simultaneously numerical solution for Equations (A11) and (A12):

$$
\begin{gathered}
\frac{I_{m p p}}{V_{m p p}}=\frac{\frac{I_{o}}{V_{T}} e^{\frac{\left(V_{m p p}+I_{m p p} R_{s}\right)}{V_{T}}}+\frac{1}{R_{s h}}}{1+\frac{R_{s}}{R_{s h}}+\frac{I_{o} R_{s}}{V_{T}} e^{\frac{\left(V_{m p p}+I_{m p p} R_{s}\right)}{V_{T}}}} \\
I_{m p p}=I_{L}-I_{o}\left(e^{\frac{\left(V_{m p p}+I_{m p p} R_{s}\right)}{V_{T}}}-1\right)-\frac{V_{m p p}+I_{m p p} R_{s}}{R_{s h}}
\end{gathered}
$$

Another method to calculate $V_{m p p}$ and $I_{m p p}$ [50], where $V_{m p p}$ is given as in Equations (A13) and (A14) respectively:

$$
\begin{gathered}
V_{m p p}=V_{T} \ln \left(\frac{I_{s c}-I_{m p p}}{I_{O}}+1\right)-I_{m p p} R_{s} \\
I_{m p p}+\frac{\left(I_{m p p}-I_{s c}-I_{o}\right)\left[\ln \left(\frac{I_{s c}-I_{m p p}}{I_{o}}+1\right)-\frac{I_{m p p} R_{s}}{V_{T}}\right]}{1+\left(I_{m p p}-I_{s c}-I_{o}\right) \frac{R_{s}}{V_{T}}}=0
\end{gathered}
$$

where $I_{m p p}$ can be calculated starting from an initial guess and using numerical root-finding algortigms such as those implemented in fsolve or fzero functions of the MATLAB software. Then, the resulting value of $I_{m p p}$ can be substituted in Equation (A14) to get $V_{m p p}$. 


\section{References}

1. Salam, M.A.; Khan, S. Transition towards sustainable energy production-A review of the progress for solar energy in Saudi Arabia. Energy Explor. Exploit. 2017, 36, 3-27. [CrossRef]

2. El-Sebaii, A.A.; Al-Agel, F. Estimation of horizontal diffuse solar radiation from common meteorological parameters: A case study for Jeddah, Saudi Arabia. Int. J. Ambient. Energy 2013, 34, 92-99. [CrossRef]

3. Ahmad, N.I.; Kadir, M.Z.A.; Izadi, M.N.H.; Zaini, M.A.; Radzi, M.; Azis, N. Effect of temperature on a poly-crystalline solar panel in large scale solar plants in Malaysia. In Proceedings of the IEEE Conference on Energy Conversion (CENCON), Johor Bahru, Malaysia, 19-20 October 2015; pp. 244-248. [CrossRef]

4. Sabri, L.; Benzirar, M. Effect of Ambient Conditions on Thermal Properties of Photovoltaic Cells: Crystalline and Amorphous Silicon. Int. J. Innov. Res. Sci. Eng. Technol. 2014, 3, 17815-17821. [CrossRef]

5. Sahri, A.; Toumi, S.; Ramenah, H.; Tanougast, C. Temperature effects on the power production based photovoltaic cells. In Proceedings of the 25th International Conference on Microelectronics (ICM), Beirut, Lebanon, 15-18 December 2013; pp. 1-4. [CrossRef]

6. Elnozahy, A.; Rahman, A.K.A.; Ali, A.H.H.; Abdel-Salam, M.; Ookawara, S. Performance of a PV module integrated with standalone building in hot arid areas as enhanced by surface cooling and cleaning. Energy Build. 2015, 88, 100-109. [CrossRef]

7. Elnozahy, A.; Rahman, A.K.A.; Ali, A.H.H.; Abdel-Salam, M.; Ookawara, S. Thermal/Electrical Modeling of a PV Module as Enhanced by Surface Cooling. J. Clean Energy Technol. 2015, 4, 1-7. [CrossRef]

8. Røyne, A.; Dey, C.; Mills, D. Cooling of photovoltaic cells under concentrated illumination: A critical review. Sol. Energy Mater. Sol. Cells 2005, 86, 451-483. [CrossRef]

9. Bahaidarah, H.M.S. Experimental performance investigation of uniform and non-uniform cooling techniques for photovoltaic systems. In Proceedings of the IEEE 42nd Photovoltaic Specialist Conference (PVSC), New Orleans, LA, USA, 14-19 June 2015; pp. 1-4. [CrossRef]

10. Cazzaniga, R.; Rosa-Clot, M.; Rosa-Clot, P.; Tina, G.M. Floating tracking cooling concentrating (FTCC) systems. In Proceedings of the 38th IEEE Photovoltaic Specialists Conference, Austin, TX, USA, 3-8 June 2012; pp. 514-519. [CrossRef]

11. Colţ, G. Performance evaluation of a PV panel by rear surface water active cooling. In Proceedings of the International Conference on Applied and Theoretical Electricity (ICATE), Craiova, Romania, 16-17 December 2016; pp. 1-5. [CrossRef]

12. Sreejith, C.S.; Rajesh, P.; Unni, M.R. Experimental study on efficiency enhancement of PV systems with combined effect of cooling and maximum power point tracking. In Proceedings of the International Conference on Inventive Computation Technologies (ICICT), Coimbatore, India, 26-27 August 2016; pp. 1-5. [CrossRef]

13. Adhya, D.; Bhattacharjee, S.; Acharya, S. Back surface cooling of photovoltaic panel—An experimental investigation. In Proceedings of the IEEE 6th International Conference on Power Systems (ICPS), New Delhi, India, 4-5 March 2016; pp. 1-6. [CrossRef]

14. Sun, X.; Dubey, R.; Chattopadhyay, S.; Khan, M.R.; Chavali, R.V.; Silverman, T.J.; Kottantharayil, A.; Vasi, J.; Alam, M.A. A novel approach to thermal design of solar modules: Selective-spectral and radiative cooling. In Proceedings of the IEEE 43rd Photovoltaic Specialists Conference (PVSC), Portland, OR, USA, 5-10 June 2016; pp. 3584-3586. [CrossRef]

15. Raina, G.; Thakur, N.S. Mathematical approach for optimizing heat sink for cooling of solar PV module. Int. J. Sci. Eng. Res. 2019 (IJSER) 2019, 7, 62-66.

16. Soliman, A.M.; Hassan, H.; Ookawara, S. An experimental study of the performance of the solar cell with heat sink cooling system. Energy Procedia 2019, 162, 127-135. [CrossRef]

17. Cuce, E.; Bali, T.; Sekucoglu, S.A. Effects of passive cooling on performance of silicon photovoltaic cells. Int. J. Low-Carbon Technol. 2011, 6, 299-308. [CrossRef]

18. Popovici, C.G.; Hudișteanu, S.-V.; Mateescu, T.D.; Chereches, N.-C. Efficiency Improvement of Photovoltaic Panels by Using Air Cooled Heat Sinks. Energy Procedia 2016, 85, 425-432. [CrossRef]

19. Hassan, I.A. Enhancement the Performance of PV Panel by Using Fins as Heat Sink. Eng. Technol. J. 2018, 36, 798-805. 
20. Arifin, Z.; Tjahjana, D.P.; Hadi, S.; Rachmanto, R.A.; Setyohandoko, G.; Sutanto, B. Numerical and Experimental Investigation of Air Cooling for Photovoltaic Panels Using Aluminum Heat Sinks. Int. J. Photoenergy 2020, 2020, 1-9. [CrossRef]

21. Hassan, Y.; Orabi, M.; Ismeil, M.; Alshreef, A.; Al-Rabghi, O.M. Steady State Analysis of Solar Energy Transmitted to Solar Panel in Hot Weather Environment and Various Wind Speed. In Proceedings of the 2019 IEEE International Conference on Sustainable Energy Technologies and Systems (ICSETS), Bhubaneswar, India, 26 February-1 March 2019; pp. 36-44. [CrossRef]

22. Seethamraju, S.; Ramamurthy, P.C.; Madras, G. Encapsulation for Improving the Efficiencies of Solar Cells; Materials and Processes for Solar Fuel Production 2014, Nanostructure Science and Technology Book Series; Springer: New York, NY, USA, 2014; Volume 174. [CrossRef]

23. Hammami, M.; Torretti, S.; Grimaccia, F.; Grandi, G. Thermal and Performance Analysis of a Photovoltaic Module with an Integrated Energy Storage System. Appl. Sci. 2017, 7, 1107. [CrossRef]

24. Hersel, P.; Zweibel, K. Basic Photovoltaic Principles and Methods; Solar Energy Research Institute: Golden, CO, USA, 1982.

25. Ramsurn, H.; Gupta, R.B. Nanotechnology in Solar and Biofuels. ACS Sustain. Chem. Eng. 2013, 1, $779-797$. [CrossRef]

26. Dubey, S.; Sarvaiya, J.N.; Seshadri, B. Temperature Dependent Photovoltaic (PV) Efficiency and Its Effect on PV Production in the World-A Review. Energy Procedia 2013, 33, 311-321. [CrossRef]

27. Anurag, A.; Zhang, J.; Gwamuri, J.; Pearce, J.M. General Design Procedures for Airport-Based Solar Photovoltaic Systems. Energies 2017, 10, 1194. [CrossRef]

28. Bai, Y.; Chow, T.T.; Ménézo, C.; Dupeyrat, P.; Mé Né Zo, C. Analysis of a Hybrid PV/Thermal Solar-Assisted Heat Pump System for Sports Center Water Heating Application. Int. J. Photoenergy 2012, 2012, 1-13. [CrossRef]

29. Teo, H.; Lee, P.-S.; Hawlader, M. An active cooling system for photovoltaic modules. Appl. Energy 2012, 90, 309-315. [CrossRef]

30. Elsafi, A.M.; Gandhidasan, P. Comparative study of double-pass flat and compound parabolic concentrated photovoltaic-thermal systems with and without fins. Energy Convers. Manag. 2015, 98, 59-68. [CrossRef]

31. Duffie, J.A.; Beckman, W.A. Solar Engineering of Thermal Processes, 2nd ed.; John Wiley \& Sons: New York, NY, USA, 1991.

32. Cengel, Y.A. Introduction to Thermodynamics and Heat Transfer, 2nd ed.; McGraw-Hill: New York, NY, USA, 2008.

33. Alieva, Z.; Nosirov, M.; Mukhtarov, E. The thermal conductivity of solar-cell wafers molded from a powdered stock. Appl. Sol. Energy 2014, 50, 110-112. [CrossRef]

34. Ngo, I.-L.; Jeon, S.; Byon, C. Thermal conductivity of transparent and flexible polymers containing fillers: A literature review. Int. J. Heat Mass Transf. 2016, 98, 219-226. [CrossRef]

35. Chen, Y.; Zhuo, F.; Liu, X.; Xiong, L. Thermal modelling and performance assessment of PV modules based on climatic parameters. In Proceedings of the 2015 IEEE Energy Conversion Congress and Exposition (ECCE), Montreal, QC, Canada, 20-24 September 2015; pp. 3282-3286. [CrossRef]

36. Kumar, S.; Mullick, S. Wind heat transfer coefficient in solar collectors in outdoor conditions. Sol. Energy 2010, 84, 956-963. [CrossRef]

37. Kumar, A.M.; Balasubramanian, M. VAWT which makes use of the turbulent winds generated by the highway traffic. In Proceedings of the IACSIT International Journal of Engineering and Technology, Beijing, China, 16-17 June 2012; Volume 4.

38. Devi, R.; Singh, J. Design and development of prototype highway lighting with road side wind energy harvester. Int. J. Sci. Res. 2014, 3, 1681-1683.

39. Passmore, M.A. The Measurement and Analysis of Road Vehicle Drag Forces. Ph.D. Thesis, (Aeronautical and Automotive Engineering). Loughborough University, London, UK, 1990. Available online: https: //dspace.lboro.ac.uk/2134/7038 (accessed on 1 January 1990).

40. Abdulkareem, S.H.; Al-Obaidi, M.; Sun, L.C. Calculation and optimization of the aerodynamic drag of an open-wheel race car. In Proceedings of the 1st Engineering Undergraduate Research Catalyst Conference, Kuala Lumpur, Malaysia, 1-15 Auguest 2014. 
41. Tiwari, G.N.; Sahota, L. Advanced solar-distillation systems basic principles, thermal modeling and its application. In Green Energy and Technology; Springer Nature Singapore Pte Ltd.: New Delhi, India, 2017.

42. Migan, G.A. Study the Operating Temperature of a PV Module; Project Report; MVK160 Heat and Mass Transfer: Lund, Sweden, 2013.

43. Wenham, S.R.; Green, M.A.; Watt, M.E.; Corkish, R. Applied Photovoltaics, 2nd ed.; Earthscan: London, UK, 2006; pp. 33-83.

44. Schwingshackl, C.; Petitta, M.; Wagner, J.E.; Belluardo, G.; Moser, D.; Castelli, M.; Zebisch, M.; Tetzlaff, A. Wind effect on PV module temperature: Analysis of different techniques for an accurate estimation. Energy Proc. 2013, 40, 77-86. [CrossRef]

45. Skoplaki, E.; Boudouvis, A.G.; Palyvos, J.A. A simple correlation for the operating temperature of photovoltaic modules of arbitrary mounting. Sol. Energy Mater. Sol. C 2008, 92, 1393-1402. [CrossRef]

46. Ciulla, G.; Brano, V.L.; Moreci, E. Forecasting the cell temperature of PV modules with an adaptive system. Int. J. Photoenergy 2013, 2013, 192854. [CrossRef]

47. Azzouzi, M.; Popescu, D.; Bouchahdane, M. Modeling of electrical characteristics of photovoltaic cell considering single-diode model. J. Clean Energy Technol. 2016, 4, 414-420. [CrossRef]

48. Rodrigues, E.M.; Melicio, R.; Mendes, V.M.; Catalao, J.P. Simulation of a solar cell considering single-diode equivalent circuit model. In Proceedings of the International Conference on Renewable Energies and Power Quality, Las Palmas de Gran Canaria, Spain, 13-15 April 2011.

49. Masters, G.M. Renewable and Efficient Electric Power Systems; Wiley: Hoboken, NJ, USA, 2004.

50. Sethi, V.P.; Sumathy, K.; Yuvarajan, S.; Pal, D.S. Mathematical model for computing maximum power output of a PV solar module and experimental validation. J. Fund. Renew. Energy Appl. 2012, 2, 1-5. [CrossRef]

51. Culham, J.R.; Khan, W.; Yovanovich, M.; Muzychka, Y.S. The influence of material properties and spreading resistance in the thermal design of plate fin heat sinks. J. Electron. Packag. 2007, 129, 76-81. [CrossRef]

52. Cucumo, M.; Ferraro, V.; Kaliakatsos, D. Theoretical and experimental analysis of the performances of a heat sink with vertical orientation in natural convection. Int. J. Energy Environ. Eng. 2017, 8, 247. [CrossRef]

53. Guitart Corominas, J. Heat Sink Analytical Modelling; UPC, Universitat Politècnica de Catalunya BarcelonaTech: Barcelona, Spain, 2011.

54. Song, S.; Lee, S.; Au, V. Closed-Form Equation for Thermal Constriction/Spreading Resistances with Variable Resistance Boundary Conditions. In Proceedings of the IEPS Conference, Atlanta, GA, USA, 11-15 July 1995; pp. 111-121.

55. Werdowatz, A.R. Developing an Empirical Correlation for the Thermal Spreading Resistance of a Heat Sink. Master's Thesis, San Jose State University, San Jose, CA, USA, 2016. Available online: http: //scholarworks.sjsu.edu/etd_theses/4711 (accessed on 1 May 2016).

56. Yovanovich, M.M.; Marotta, E.E. Thermal Spreading and Contact Resistances; Book Chapter, Heat Transfer Handbook; John Wiley: Hoboken, NJ, USA, 2003.

57. Kraus, A.D.; Bar-Cohen, A. Design and Analysis of Heat Sinks; Wiley: New York, NY, USA, 1995.

58. Aweda, J.O.; Adeyemi, M.B. Experimental determination of heat transfer coefficients during squeeze casting of aluminum. J. Mater. Process Technol. 2009, 209, 1477-1483. [CrossRef]

59. Zell, E.; Gasim, S.; Wilcox, S.; Katamoura, S.; Stoffel, T.; Shibli, H.; Engel-Cox, J.; Al Subie, M. Assessment of solar radiation resources in Saudi Arabia. Sol. Energy 2015, 119, 422-438. [CrossRef]

60. Almazroui, M.; Tayeb, O.; Mashat, A.S.; Yousef, A.; Al-Turki, Y.A.; Abid, M.A.; Bafail, A.O.; Ehsan, M.A.; Zahed, A.; Rahman, M.A.; et al. Saudi-KAU coupled global climate model: Description and performance. Earth Syst. Environ. 2017. [CrossRef]

61. Rehman, S.; Alam, M.; Meyer, J.; Al-Hadhrami, L. Long-Term Wind Speed Trends over Saudi Arabia; King Fahd University of Petroleum and Minerals: Dhahran, Saudi Arabia, 2012. [CrossRef]

62. The General Authority of Meteorology and Environment Protection, Saudi Arabia. Available online: https://www.pme.gov.sa/en/meteorology/pages/climatereport.aspx (accessed on 1 June 2018).

(C) 2020 by the authors. Licensee MDPI, Basel, Switzerland. This article is an open access article distributed under the terms and conditions of the Creative Commons Attribution (CC BY) license (http://creativecommons.org/licenses/by/4.0/). 